\title{
Response of a Lake Michigan coastal lake to anthropogenic catchment disturbance
}

\author{
Julie A. Wolin ${ }^{1, *}$ and Eugene F. Stoermer ${ }^{2}$ \\ ${ }^{1}$ Department of Biological, Geological and Environmental Sciences, Cleveland State University, Cleveland, \\ OH 44115, USA; ${ }^{2}$ School of Natural Resources and Environment, University of Michigan, Ann Arbor, MI \\ 48109, USA; *Author for correspondence (e-mail: j.wolin@csuohio.edu)
}

Received 20 March 2004; accepted in revised form 6 July 2004

Key words: Diatoms, Eutrophication, Geochemistry, Lake Michigan, Paleolimnology

\begin{abstract}
A paleolimnological investigation of post-European sediments in a Lake Michigan coastal lake was used to examine the response of Lower Herring Lake to anthropogenic impacts and its role as a processor of watershed inputs. We also compare the timing of this response with that of Lake Michigan to examine the role of marginal lakes as 'early warning' indicators of potential changes in the larger connected system and their role in buffering Lake Michigan against anthropogenic changes through biotic interactions and material trapping. Sediment geochemistry, siliceous microfossils and nutrient-related morphological changes in diatoms, identified three major trophic periods in the recent history of the lake. During deforestation and early settlement (pre-1845-1920), lake response to catchment disturbances results in localized increases in diatom abundances with minor changes in existing communities. In this early phase of disturbance, Lower Herring Lake acts as a sediment sink and a biological processor of nutrient inputs. During low-lake levels of the 1930s, the lake goes through a transitional period characterized by increased primary productivity and a major shift in diatom communities. Post-World War II (late 1940s-1989) anthropogenic disturbances push Lower Herring Lake to a new state and a permanent change in diatom community structure dominated by Cyclotella comensis. The dominance of planktonic summer diatom species associated with the deep chlorophyll maximum (DCM) is attributed to epilimnetic nutrient depletion. Declining Si:P ratios are inferred from increased sediment storage of biogenic silica and morphological changes in the silica content of Aulacoseira ambigua and Stephanodiscus niagarae. Beginning in the late 1940s, Lower Herring Lake functions as a biogeochemical processor of catchment inputs and a carbon, nutrient and silica sink. Microfossil response to increased nutrients and increased storage of biogenic silica in Lower Herring Lake and other regional embayments occur approximately 20-25 years earlier than in a nearby Lake Michigan site. Results from this study provide evidence for the role of marginal lakes and bays as nutrient buffering systems, delaying the impact of anthropogenic activities on the larger Lake Michigan system.
\end{abstract}

\section{Introduction}

European settlement of the Great Lakes produced a lasting impact on these aquatic ecosystems (e.g.,
Stoermer et al. 1985a, 1987; Schelske 1991). The rate and degree of change varies with time and location within the system (Stoermer et al. 1993). Certain post-European settlement periods exhibit 
large changes in ecological forcing functions (Schelske 1991) and biotic responses (Stoermer 1993). Following World War II, use of chemical fertilizers in agriculture and introduction of phosphate detergents combined to increase nutrient loadings in the Great Lakes basin. Anthropogenic impacts in the Lake Michigan basin have been reported by several investigators (Stoermer et al. 1990, 1991; Fritz et al. 1993). Though timing of these events vary depending on the site, these signals first appear in marginal lakes and embayments before being translated into Lake Michigan itself. In this paper, we revisit analysis of postsettlement lake sediments collected from Lower Herring Lake, Michigan to investigate timing of this signal in relation to that recorded in Lake Michigan and the implications for the role of marginal lakes in interpreting ecological change in large lakes. Two functions are of particular interest: (1) Marginal lakes as 'early warning' indicators of potential changes in the larger connected system. (2) The role of marginal lakes in buffering Lake Michigan against anthropogenic changes through biotic interactions and material trapping.

Marginal lakes are part of a network of nutrient and mineral processors occurring in freshwater aquatic systems that act as 'sinks' for materials draining off the landscape, or sources of materials to downstream systems. Each 'downstream' component is dependent on the processes occurring before it. Intensive utilization of nutrients upstream can create limiting conditions below. Conley et al. (1993) and Conley (2000) extensively document the result of upstream nutrient loadings on utilization processes and alterations of biogeochemical cycles in lakes and marine coastal environments.

Marginal lakes and wetlands in the Great Lakes basin are important processors of nutrients and sediments in the watershed, however few studies have investigated their recent response to anthropogenic impacts and the environmental interactions of these coastal environments with their associated lake (e.g., Earle and Duthie 1986, Second Marsh/Lake Ontario; Yang et al. 1993, Wolfe et al. 2000, Hamilton Harbor/Lake Ontario and Krieger 2003, Old Woman Creek/Lake Erie). The ability of any lake system to absorb and process materials is related to its size, trophic status, and human activities in the watershed (Dixit et al. 1999). Additionally, marginal lakes and embay- ments are affected by the degree of connectivity they have to the adjacent lake. A high degree of connectivity may actually moderate anthropogenic impacts in the smaller system, as in the case of Hamilton Harbor and Lake Ontario (Wolfe et al. 2000).

In recent years, greater development of lakeshore properties, increased population densities and conversion of summer cottages to year-round residences have increased human pressures on lake ecosystems (Garrison and Wakeman 2000; Ramstack et al. 2003). In the Great Lakes basin, these impacts can affect the capacity of marginal lake systems to process non-point source pollution. It is therefore important to determine lake response to past disturbances in order to predict the future capacity of these marginal systems to process inputs. Such information is critical for developing informed watershed management decisions concerning these important coastal resources (Baron et al. 2002).

Diatom and chrysophyte microfossils have been used extensively in paleolimnology as surrogate recorders of environmental change resulting from natural and anthropogenic processes (e.g., Stoermer et al. 1993; Smol 1995; Hall and Smol 1999; Bradbury et al. 2002; Forrest et al. 2002; Ramstack et al. 2003; Siver et al. 2003). An investigation into long-term ecological change in Lower Herring Lake (Wolin 1996) revealed two significant events in the lake's history: isolation from Lake Michigan (ca. 2200-2000 years BP), and the effects of European settlement which continue today. In this paper, we analyze the post-European geochemical and siliceous microfossil sediment record to examine the response of Lower Herring Lake to anthropogenic impacts and compare the timing of this response with that of Lake Michigan. We also utilize geochemical data, diatom assemblage and nutrient-related morphological changes as evidence for biotic interactions within Lower Herring Lake and its role as a processor of watershed inputs.

\section{Land use history}

Deforestation of the Herring Lake basin began ca. AD 1845 (Glarum 1983). Milling operations were established on Herring Creek in 1851 and continued sporadically until a forest fire swept through 
the basin in 1867. A small settlement and mill existed on the southern shore of the lake between 1890 and 1896. This settlement became a resort in the early 1900s. Since then, Lower Herring Lake has primarily been used for summer cottages and recreational purposes.

\section{Modern limnology}

Lower Herring Lake is a mesotrophic, alkaline lake $(\mathrm{pH}=7.5-8.5)$ located in the northern lower peninsula of Michigan ( $44^{\circ} 33^{\prime} 44^{\prime \prime} \mathrm{N}, 86^{\circ} 12^{\prime} 38^{\prime \prime} \mathrm{W}$, Figure 1$)$. It is moderately deep $\left(Z_{\max }=20.6 \mathrm{~m}\right.$, 1990) with a surface $A=182$ ha and $56.5 \mathrm{~km}^{2}$ drainage basin. The main axis of Lower Herring Lake lies north-south with prevailing winds traveling across Lake Michigan from the southwest in summer and northwest in winter, exposing the lake to strong mixing forces. The influence of Lake Michigan is also seen in the moderation of air temperatures, creating longer cooling periods in fall and warming periods in spring. Ice cover typically lasts from December to mid-March.

Historic water chemistry data from 1955, 1974, and 1985 were obtained from the Michigan Department of Natural Resources (DNR). These data indicate hypolimnetic summer anoxia existing as far back as 1955. Fisheries surveys from 1955 indicate healthy populations of ciscoe, but noted an August die-off. Sulfur odor problems and fish kills were also reported in September 1974.

Monthly physical-chemical measurements and surface phytoplankton samples were taken by the primary author from April through November of 1986. These data indicate the lake stratified from June through August with metalimnion formation around $10 \mathrm{~m}$. Fall turnover occurred near the end of September. Dissolved silica concentrations $\left(\mathrm{SiO}_{2}\right)$ during spring turnover (late April) were $9.2 \mathrm{mg}^{-1}$ with lowest epilimnetic summer concentrations of $0.94 \mathrm{mg}^{-1}$ occurring in June and July. Epilimnetic total phosphorus (TP) measured $18 \mu \mathrm{g}^{-1}$ in April and $31 \mu \mathrm{g} \mathrm{1^{-1 }}$ in May. Concen-

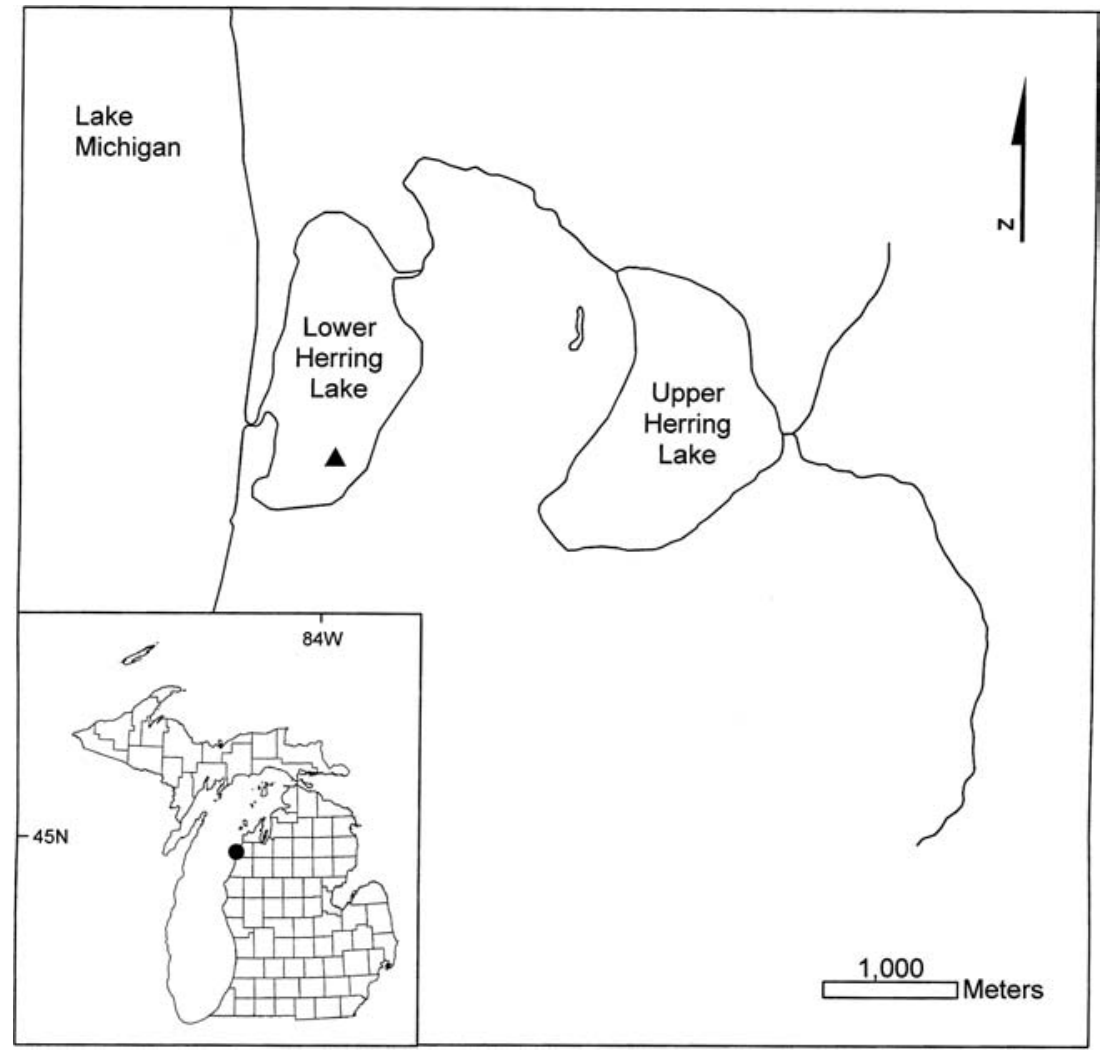

Figure 1. Map of Michigan showing location of Lower Herring Lake

Core site is indicated by 
trations were between 10 and $16.5 \mu \mathrm{g} 1^{-1}$ during stratification and increased to $42.5 \mu \mathrm{g}^{-1}$ during mixing in September. Nitrate surface concentrations were highest in April $\left(740 \mu \mathrm{g} 1^{-1}\right)$ following snow melt. Concentrations decline to $150 \mu \mathrm{g} 1^{-1}$ during stratification, and lowest amounts (90 $\mu \mathrm{g}^{-1}$ ) occur during fall mixing. Many of the cottages surrounding the lake are on septic and originally were built as summer homes in the 1940s and 1950s. More recently, many have been converted to year-round residences. Leakage from defective septic systems and lawn fertilization are two probable nitrate sources during the 1980s.

Stephanodiscus niagarae and Asterionella formosa dominated the spring phytoplankton (April and May 1986) while Fragilaria crotonensis, Aulacoseira ambigua, Mallomonas, and Dinobryon species were common. Fragilaria crotonensis was the dominant summer diatom (June-August) along with blooms of $C$. comensis in June, A. formosa in July, and increasing abundances of Ceratium and cyanobacteria in August. Oscillatoria was the predominant cyanobacterium in September. Aulacoseira ambigua was dominant in the fall (September-November) during turbulent conditions. Stephanodiscus niagarae reappeared in September during mixing, increasing in abundance through November.

\section{Methods}

\section{Coring}

A $3.9 \mathrm{~m}$ core was obtained from a depth of $15.25 \mathrm{~m}$ in Lower Herring Lake using a modified Livingstone piston corer (Wright 1991) in September 1989. The top section of the core used in this study was collected with a polycarbonate tube and extruded vertically to preserve all surficial sediments. Samples were sectioned in $1 \mathrm{~cm}$ intervals in the field, stored in Whirl-pak bags, refrigerated and then freeze-dried upon return to the laboratory.

\section{Chronology}

The upper $40 \mathrm{~cm}$ of the core was dated in 1990 by Dr Claire Schelske, Department of Fisheries and Aquaculture, University of Florida. Samples were analyzed for ${ }^{137} \mathrm{Cs}$ and ${ }^{210} \mathrm{~Pb}$ to determine age and sediment accumulation rates for the past 100
150 years. The top section $(0-1 \mathrm{~cm})$ was not analyzed due to lack of material. Sediments were dated using the low-background gamma-counting method (Appleby et al. 1986) with a well-type germanium detector (EG\&G Ortec) and a 4096channel pulse-height analyzer. Samples were processed according to procedures in Wolin (1996). Ages were calculated from the unsupported ${ }^{210} \mathrm{~Pb}$ activity using the constant rate of supply (c.r.s.) model (Appleby and Oldfield 1983).

\section{Geochemistry}

Sediment composition was estimated using losson-ignition techniques (Dean 1974). Weighed subsamples (100-200 mg) were taken from each $1 \mathrm{~cm}$ level and oven dried to remove any excess water. Organic matter and carbonate content were determined by calculating loss of mass at 550 and $1000{ }^{\circ} \mathrm{C}$, respectively.

Biogenic silica concentrations were determined for each $\mathrm{cm}$ of the core based on methods developed by DeMaster $(1979,1981)$ where samples are digested in a $1 \% \mathrm{Na}_{2} \mathrm{CO}_{3}$ solution at $85^{\circ} \mathrm{C}$ on a time-series basis. Aliquots of sample are removed for analysis at 2, 3, and $4 \mathrm{~h}$ intervals (Wolin 1996). Silica concentrations were determined by the heteropoly blue method (Davis and Simmons 1979) using an AutoAnalyzer II. Biogenic silica concentrations were then determined for each sample using a least squares regression (Krausse et al. 1983).

\section{Grain-size analysis}

Well-mixed sub-samples were weighed (100$400 \mathrm{mg}$ ) for each level and digested in a $1 \%$ $\mathrm{Na}_{2} \mathrm{CO}_{3}$ solution at $85^{\circ} \mathrm{C}$ for $1 \mathrm{~h}$ to dissolve biogenic silica components. Samples were rinsed with distilled water and sieved through 63 and $38 \mu \mathrm{m}$ screens to separate the sand and coarse to medium silt fractions, respectively. These fractions were dried and weighed. Depositional regions of a lake are predominantly composed of sediments in the silt and clay size fractions $(<16 \mu \mathrm{m})$ (Håkanson and Jansson 1983). In order to determine changes occurring in this principal portion of the sediments, the remaining fraction $(<38 \mu \mathrm{m})$ was analyzed for grain-size distribution using a 256- 
channel Coulter Counter particle-size analyzer. Results are expressed as median grain sizes in phi units, $\phi_{50}$ of Folk (1974), where $\phi=-\log _{2} D$ and $D$ is the diameter of the particle in $\mathrm{mm}$. Since particles in the silt and clay size fraction were predominantly $<2 \mu \mathrm{m}$, only the $50 \mu \mathrm{m}$ Coulter Counter tube was used. The $50 \mu \mathrm{m}$ tube analyzes particles in the size range of $9.97 \phi(1 \mu \mathrm{m})$ to $4.96 \phi$ $(32.08 \mu \mathrm{m})$ and samples are precise to $\pm 0.03 \phi$.

\section{Microfossil analysis}

Sediment material from the core (LHL-50-89) was sub-sampled for microfossils using the biogenic silica profile as a guide. Samples were taken at $1 \mathrm{~cm}$ intervals from 0 to 12 and $2 \mathrm{~cm}$ intervals from 12 to $40 \mathrm{~cm}$. Dating results indicate the top $40 \mathrm{~cm}$ represent the post-European history of Lower Herring Lake.

Weighed sub-samples of freeze-dried material were placed in $\mathrm{H}_{2} \mathrm{O}_{2}$ overnight, then heated to boiling. Potassium dichromate was then added to complete oxidation (van der Werff 1955). Samples were then rinsed repeatedly with distilled water. Approximately $10 \mathrm{ml}$ of $10 \% \mathrm{HCl}$ was added to remove carbonates. Samples were again rinsed to remove excess acid, then dried onto coverslips in Battarbee chambers (Battarbee 1973) and mounted in $\operatorname{Hyrax}^{\circledR}$ following Patrick and Reimer (1966).

Slides were enumerated following the procedure developed by Glover (1982). All recognizable algal remains (whole diatom valves, $3 / 4,1 / 2$ and $1 / 4$ fragments, chrysophyte cysts and scales), carbon fragments, sponge spicules and phytoliths were recorded. A minimum of 500 valves were counted for each sample. In surface samples dominated by small Cyclotella species, valves were counted until a minimum of 500 Aulacoseira species were identified in order to expose as much of the assemblage as possible. All valve counts of Aulacoseira ambigua and Stephanodiscus niagarae were further separated by degree of silicification (Stoermer et al. 1985c, 1989). Coarse-valved Aulacoseira ambigua were defined as having a valve-wall thickness of $0.5-1 \mu \mathrm{m}$. These valves were visibly thicker and appeared dark in outline. Medium-valved individuals were $\ll 0.5 \mu \mathrm{m}$ in valve-wall thickness and did not appear dark in outline. Coarse-valved Stephanodiscus niagarae, individuals were defined as those with punctae $\leq 10$ in $10 \mu \mathrm{m}$ and were more heavily silicified than medium-valved taxa. Punctae in medium-valved taxa were $>10$ in $10 \mu \mathrm{m}$. Most valves were distinctive enough to visually separate, questionable valves were measured and placed in their appropriate categories. Samples were enumerated using a Leitz Ortholux microscope with fluorite oil immersion objectives providing $1200 \times$ magnification and $1.30+$ numerical aperture.

Diatom and chrysophyte raw data were encoded and diatom fragments mathematically 'reconstituted' (based on their percentage of the whole). A local data base management system at the University of Michigan (FIDO) was used for qualitative and quantitative analysis. Diatom data were analyzed with correspondence analysis (CA, ter Braak 1995) using taxa which occurred in more than $1 \%$ of the population and were present in at least $50 \%$ of the samples. CA is an unconstrained ordination technique that allows us to identify major changes in assemblage composition.

Trends in diatom-inferred historic total phosphorus (TP) and total nitrogen (TN) concentrations were calculated in order to determine the overall direction of change for these nutrients. Estimates were determined using published total phosphorus optima in Fritz et al. (1993) from 42 Michigan lakes and phosphorus and total nitrogen optima in Reavie and Smol (2001) from 64 alkaline lakes in southeastern Ontario. Nutrient trends were determined by multiplying the species optima by the $\%$ abundance of individual taxa in a sample and summing the resultant weighted values to determine an inferred TP or TN concentration for that sample. The majority of Lower Herring Lake taxa are well represented in both data sets and lakes used in both training sets are found in the same or similar ecological regions.

\section{Results}

\section{Chronology}

${ }^{137} \mathrm{Cs}$ and ${ }^{210} \mathrm{~Pb}$ profiles and sediment accumulation rates are presented in Figure $2 \mathrm{a}-\mathrm{c}$. The ${ }^{137} \mathrm{Cs}$ peak occurs at $16 \mathrm{~cm}$ (1944 according to ${ }^{210} \mathrm{~Pb}$ dating) indicating sediment mixing and/or downward migration of cesium (Figure 2a). The age- 

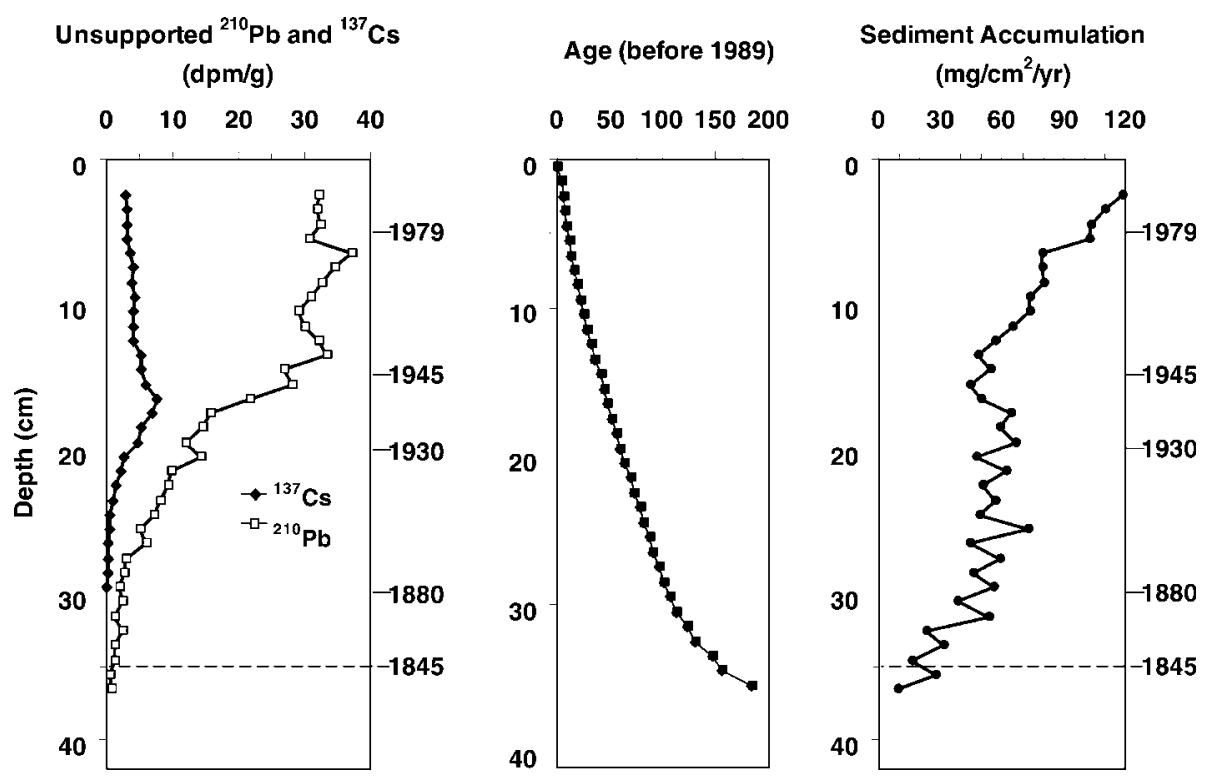

Figure 2. Unsupported ${ }^{210} \mathrm{~Pb}$ and ${ }^{137} \mathrm{Cs}$ stratigraphy (a), age-depth relationship (b), and sediment accumulation rate based on ${ }^{210} \mathrm{~Pb}$ dating (c). Dotted line represents deforestation horizon (ca. 1845).

depth relationship of ${ }^{210} \mathrm{~Pb}$ derived from the c.r.s. model is shown in Figure 2b. A deforestation signal is clearly present in the sediments at $35 \mathrm{~cm}$. Historic information places this event around AD 1845 (Glarum 1983) whereas ${ }^{210} \mathrm{~Pb}$ estimates place this sample at 1834. Because of the increasing uncertainty of ${ }^{210} \mathrm{~Pb}$ dating beyond 100 years, the stratigraphic marker of deforestation was used to date this level and was incorporated into the dating profile. Mean sedimentation rate since 1845 $(35 \mathrm{~cm})$ was calculated to be $0.0538 \mathrm{~g} \mathrm{~cm}^{-2}$ year $^{-1}$. Sediment accumulation (Figure 2c) is gradual between 1845 and 1866 then increases from 1866 to 1929. A broad peak occurs between 1929 and 1944 followed by a rapid increase in accumulation after 1957.

\section{Geochemistry}

Accumulation data from loss-on-ignition and biogenic silica analyses are shown in Figure 3. Organic matter accumulation shows a gradual increase between 35 and $31 \mathrm{~cm}$ and at $25 \mathrm{~cm}$. Other increases occur at $12 \mathrm{~cm}$ and above $5 \mathrm{~cm}$. Carbonate accumulations show a steady increase above $32 \mathrm{~cm}$, followed by a small increase be- tween 19 and $17 \mathrm{~cm}$. A decline occurs at 16-12 cm but accumulations increase again between $12 \mathrm{~cm}$ and the surface. Biogenic silica accumulations exhibit a similar pattern with a gradual increase between 32 and $24 \mathrm{~cm}$, a slight increase from 19 to $17 \mathrm{~cm}$ and a distinct increase beginning at 12 and $4 \mathrm{~cm}$.

\section{Grain size}

Size analysis of the mineral component of the core is shown in Figure 4. Silt and clay particles $(<38 \mu \mathrm{m})$ comprised $65-90 \%$ of the mineral fraction, coarse silt (38-63 $\mu \mathrm{m}) 2-35 \%$, and sand $(>63 \mu \mathrm{m}) 2-5 \%$. More than $95 \%$ of the finegrained fraction $(<38 \mu \mathrm{m})$ was composed of claysize particles $(<2 \mu \mathrm{m})$.

Increases in the sand fraction are visible at 35 $33,24-23,18-14 \mathrm{~cm}$, and at 10 and $7 \mathrm{~cm}$. The 38$63 \mu \mathrm{m}$ fraction fluctuated throughout the core. This fraction increased above $36 \mathrm{~cm}$ with the largest increases occurring between 20 and $16 \mathrm{~cm}$ (up to $35 \%$ mineral material).

Phi $50\left(\phi_{50}\right)$ values are plotted for the \% $<38 \mu \mathrm{m}$ fraction. High values indicate finer particles while lower values indicate coarser particles. 


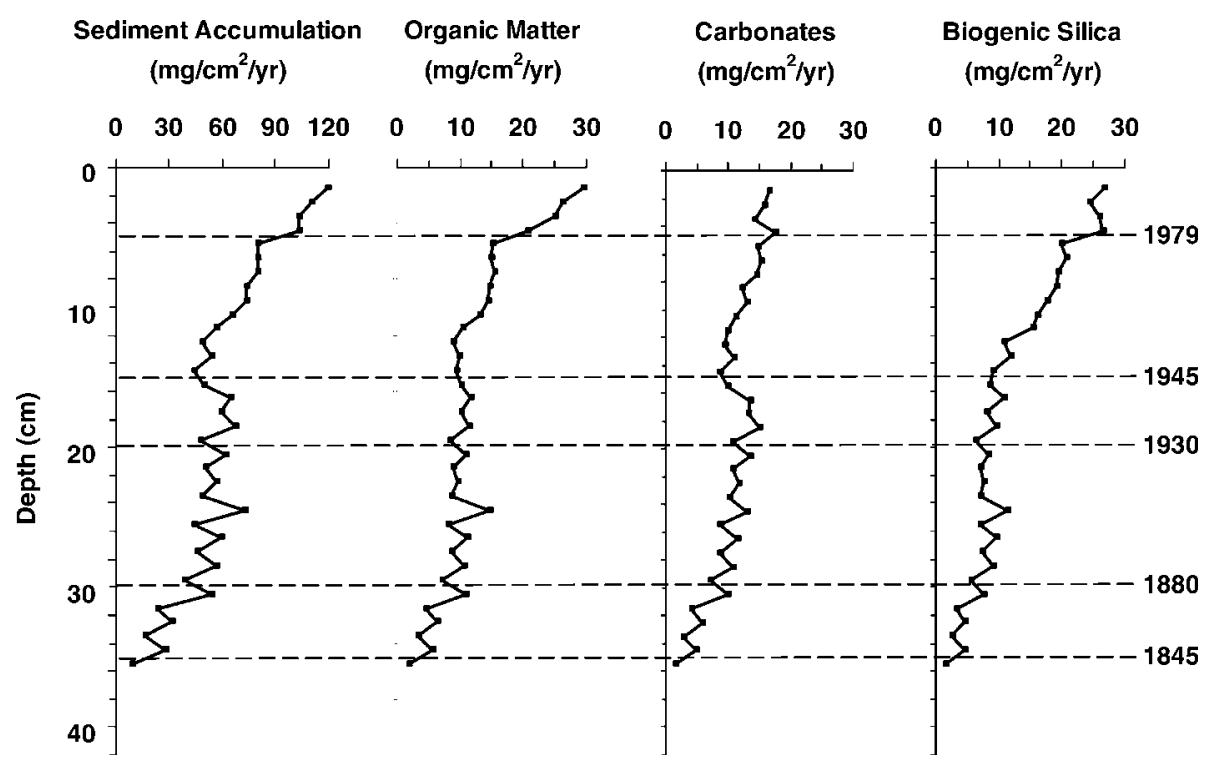

Figure 3. Geochemical profiles as accumulation rates for the upper $36 \mathrm{~cm}$ of the Lower Herring Lake core. The deforestation horizon occurs ca. 1845.

These data are influenced by the coarse-grained material ( $>38 \mu \mathrm{m})$, however, particle-size distributions provide a separate measurement of changes occurring in the fine-grained fraction. Phi 50 data indicate slightly coarser grain-sizes at $36 \mathrm{~cm}$ with much finer particles above $36 \mathrm{~cm}$ (Figure 4). Influxes of coarser-grained materials occur at 35$34,28-27$ and $24-16 \mathrm{~cm}$.

\section{Microfossil analysis}

Concentration and absolute abundance data for major microfossil groups are shown in Figure 5. The total number of microfossils remain relatively constant between 40 and $20 \mathrm{~cm}$ with a slight increase at $30 \mathrm{~cm}$. Microfossils show a gradual increase between 20 and $12 \mathrm{~cm}$ and increase

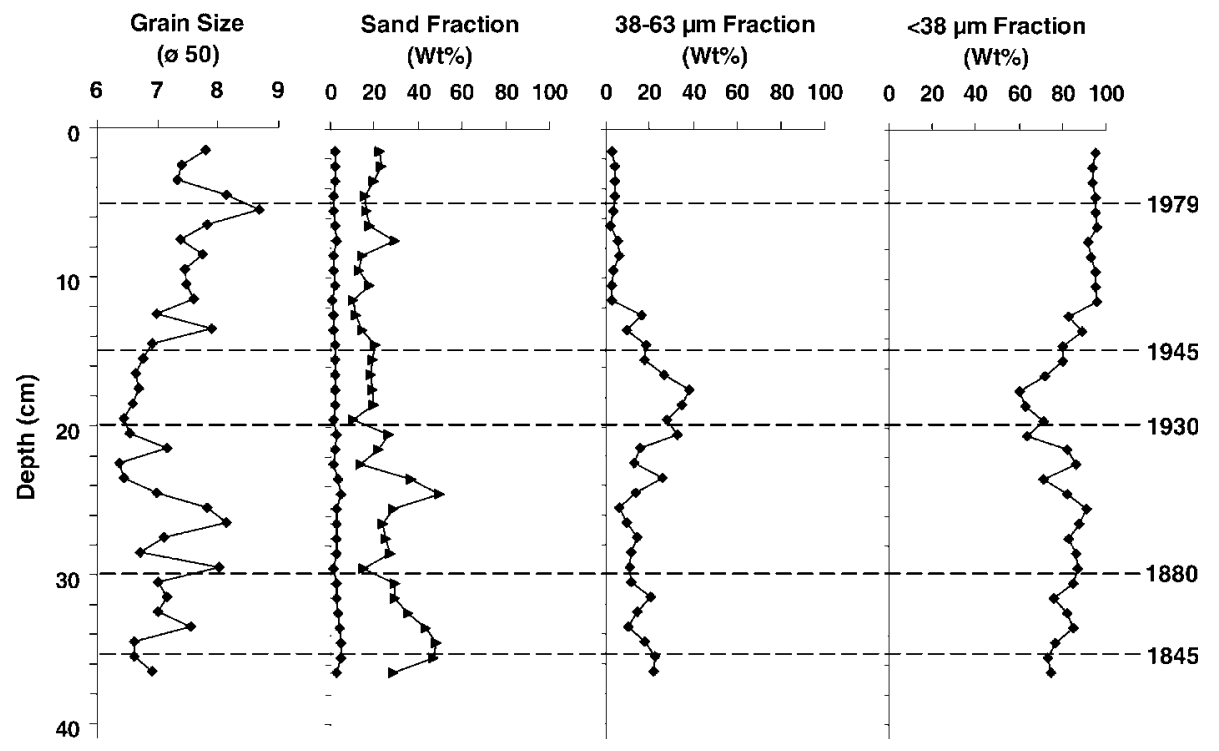

Figure 4. Grain-size distribution, sand, 38-63 $\mu \mathrm{m}$ and $<38 \mu \mathrm{m}$ fraction concentrations for the upper $36 \mathrm{~cm}$ of the Lower Herring Lake core. The deforestation horizon occurs ca. 1845. 


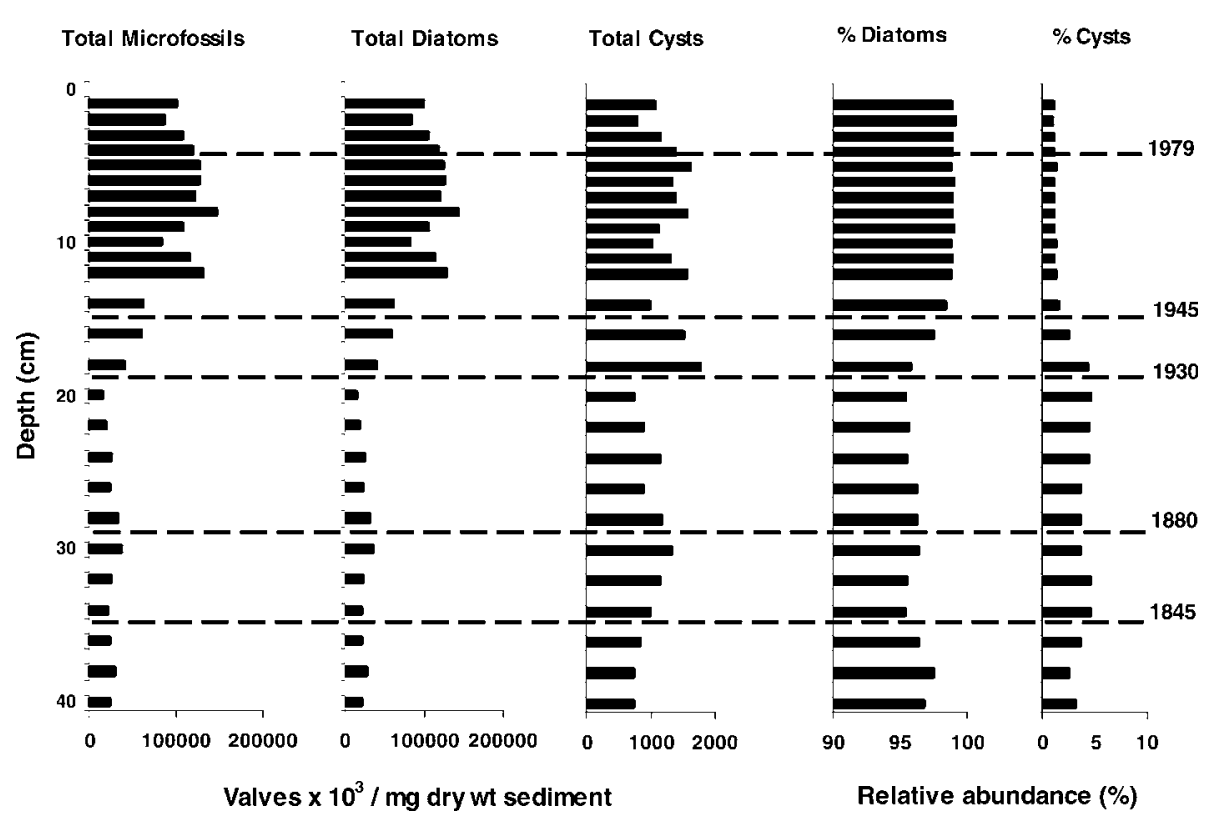

Figure 5. Relative abundance (\%) and concentration (valves $\times 10^{3} / \mathrm{mg}$ dry wt sediment) of major siliceous microfossils (diatoms and chrysophytes) in Lower Herring Lake surface sediments $(0-40 \mathrm{~cm})$.

dramatically at $12 \mathrm{~cm}$ with a slight decline in the top $4 \mathrm{~cm}$. Diatoms represent the majority of the microfossils $(>95 \%)$ and absolute abundances closely follow total microfossil profiles. Planktonic forms comprise $75-90 \%$ of the fossil diatom assemblage. Chrysophycean cysts are present in low numbers throughout, with increases visible at $30,16-18,12$ and $5 \mathrm{~cm}$. The highest percentages of cysts occur below $16 \mathrm{~cm}$.

Relative abundance data for selected diatom taxa are shown in Figure 6. Asterionella formosa, Diatoma tenue v. elongatum and Fragilaria crotonensis exhibit increases above $20 \mathrm{~cm}$ (1920). Asterionella formosa is present in all samples above $30 \mathrm{~cm}$ (1880). It reaches maximum \% abundance at $16 \mathrm{~cm}$ and between 7 and $8 \mathrm{~cm}$ in the upper $10 \mathrm{~cm}$ of the core. Diatoma tenue v. elongatum is only present above $18 \mathrm{~cm}$ and also reaches maximum $\%$ between 7 and $8 \mathrm{~cm}$ in the core. Fragilaria crotonensis is present in all samples but shows increases between 20 and $12 \mathrm{~cm}$, reaching highest percentages between 10 and $12 \mathrm{~cm}$ and in the surface. Fragilaria capucina is present in the lower portion of the core and percentages increase above $32 \mathrm{~cm}$ with peak percentages at 22 and $18 \mathrm{~cm}$. Tabellaria flocculosa has highest \% abundance below $30 \mathrm{~cm}$.
Aulacoseira species dominate assemblages in the lower portion of the core (Figure 7). Aulacoseira ambigua is the largest component of this assemblage. Percent abundance is high from 40 to $20 \mathrm{~cm}$, before declining toward the surface. Concentration data indicate that, although the percentage of $A$. ambigua declines, actual numbers increase above $20 \mathrm{~cm}$ and reach a maximum at $12 \mathrm{~cm}$, remaining high in surface sediments. Aulacoseira distans and A. subarctica are present in low percentages and occur primarily in sediments below 14 and $20 \mathrm{~cm}$, respectively. Aulacoseira distans reaches maximum concentration and relative abundances below $30 \mathrm{~cm}$. Aulacoseira subarctica reaches maximum percentages at $26 \mathrm{~cm}$ and maximum concentrations at $30 \mathrm{~cm}$. It is only present in two samples above $20 \mathrm{~cm}$.

Percent abundance profiles of Cyclotella species are shown in Figure 8. Cyclotella comensis is only present in samples above $36 \mathrm{~cm}$ and does not occur below $50 \mathrm{~cm}$ in Lower Herring Lake sediments (Wolin 1996). It increases above $18 \mathrm{~cm}$ and becomes the dominant taxon. Cyclotella stelligera is present in low amounts above $36 \mathrm{~cm}$ reaching maximum percent abundance at $18 \mathrm{~cm}$ and at $8 \mathrm{~cm}$ in the upper $10 \mathrm{~cm}$. Concentrations are highest above $10 \mathrm{~cm}$ reaching a peak at $8 \mathrm{~cm}$. 


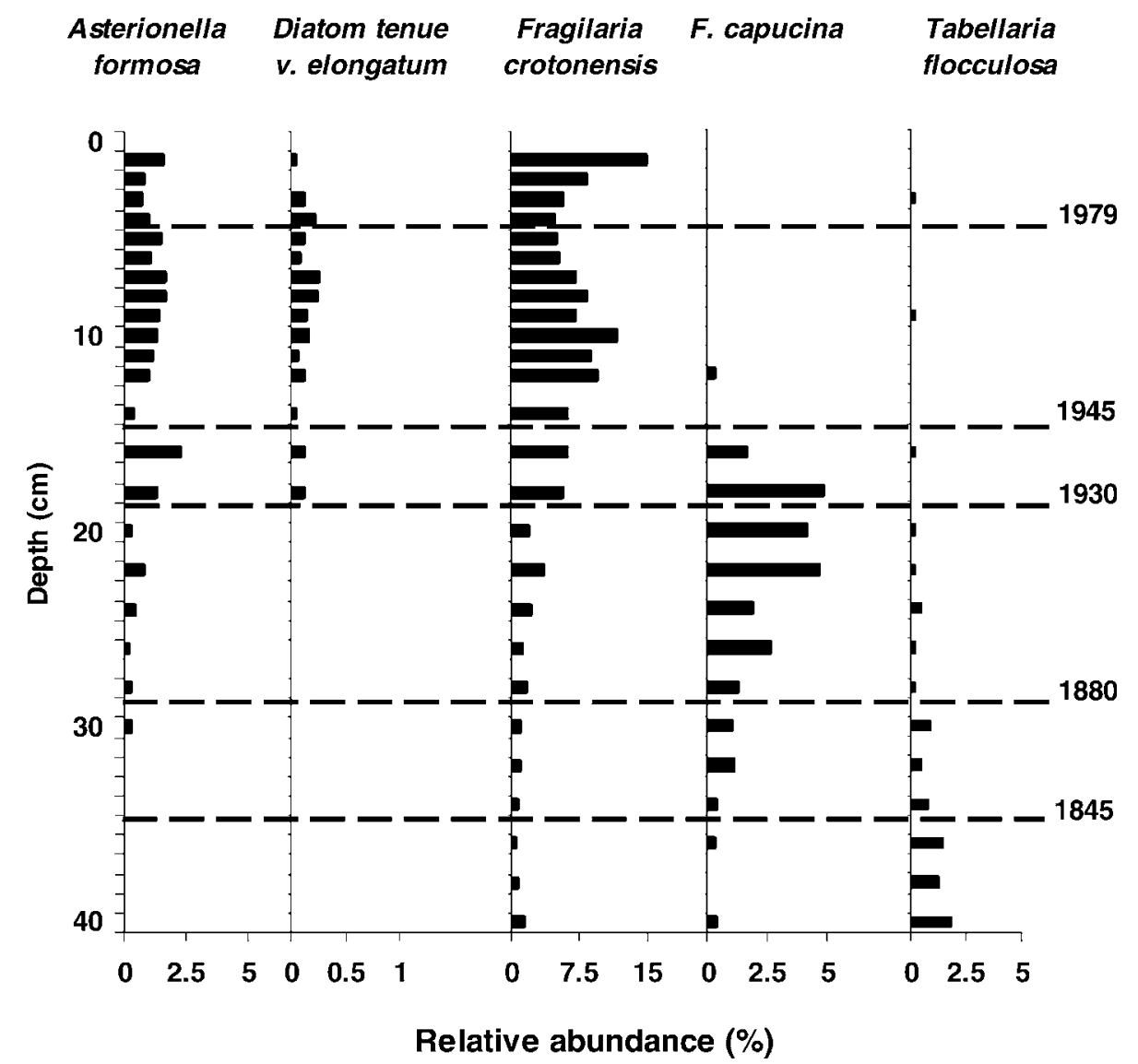

Figure 6. Relative abundance (\%) of select anthropogenic indicator taxa in Lower Herring Lake surface sediments $(0-40 \mathrm{~cm})$.

Percent abundances of Cyclotella michiganiana are highest between 30 and $18 \mathrm{~cm}$ and decline in the surface as $C$. comensis becomes dominant. Concentration data reveal that total numbers of $C$. michiganiana increase between 30 and $22 \mathrm{~cm}$, again at 18 and $12 \mathrm{~cm}$, and decline above $5 \mathrm{~cm}$. Cyclotella bodanica is present throughout the core reaching greatest concentrations and relative abundances between ca. 40 and $36 \mathrm{~cm}$ before declining.

Profiles of the three major Stephanodiscus species are shown in Figure 9. Stephanodiscus niagarae composes $10 \%$ of diatom assemblage at $40 \mathrm{~cm}$, declines from 40 to $28 \mathrm{~cm}$, increases slightly between 26 and $20 \mathrm{~cm}$ and is only a minor component above $20 \mathrm{~cm}$. Concentration data indicate, that after an initial decline between 40 and $36 \mathrm{~cm}$, $S$. niagarae numbers remain relatively constant throughout the rest of the core with small increases at $30 \mathrm{~cm}$ and in the upper $12 \mathrm{~cm}$. Concentrations and relative abundances of $S$. cf. medius exhibit a cyclical pattern throughout the core, peaking at 38, 30, 18 and $7 \mathrm{~cm}$. Morphological characteristics of this taxon fit somewhere between Stephanodiscus cf. medius and Stephanodiscus alpinus, however its features most closely resemble those of $S$. cf. medius (Håkansson and Kling 1990, Figures 34 and 35). Stephanodiscus alpinus is present in highest percentages below $26 \mathrm{~cm}$. Peak percentages occur at $36 \mathrm{~cm}$ with additional peaks at 26 , 16 , and $9 \mathrm{~cm}$. These increases in $S$. alpinus follow increases occurring in $S$. cf. medius except in the upper $10 \mathrm{~cm}$. Concentration data show that numbers of $S$. alpinus actually increase at 16 and $9 \mathrm{~cm}$ and valve numbers are highest in the upper $12 \mathrm{~cm}$ of the core.

Profiles of coarse and medium valves of Aulacoseira ambigua and Stephanodiscus niagarae are shown in Figure 10. Concentrations and relative abundances in both taxa indicate higher amounts 


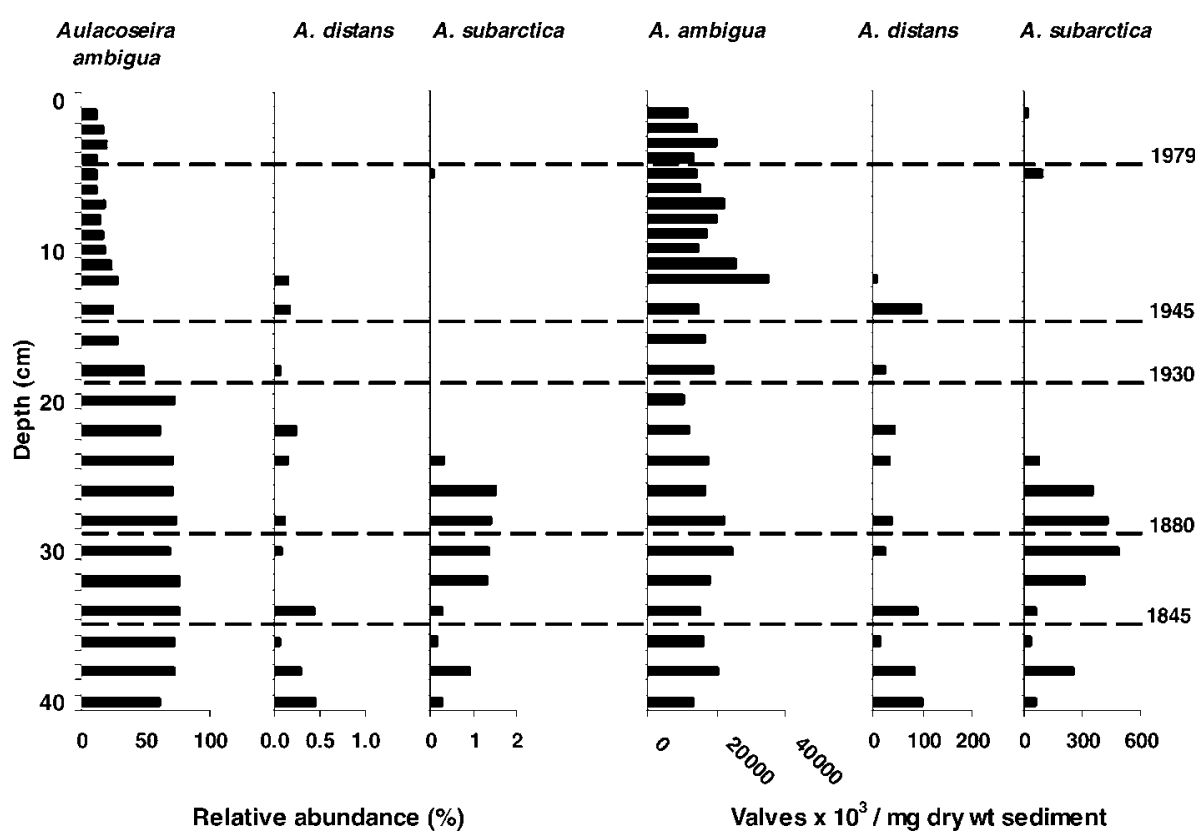

Figure 7. Relative abundance (\%) and concentration (valves $\times 10^{3} / \mathrm{mg}$ dry wt sediment) of Aulacoseira species present in Lower Herring Lake surface sediments $(0-40 \mathrm{~cm})$.

of coarse valves below $20 \mathrm{~cm}$ and an increase in medium-silicified valves above $16 \mathrm{~cm}$ for $A$. ambigua and above $12 \mathrm{~cm}$ for $S$. niagarae. One should note that, although this pattern is present, coarsely silicified valves are still the dominant form in both assemblages.

Results of correspondence analysis (CA) indicate the majority of the assemblage data are

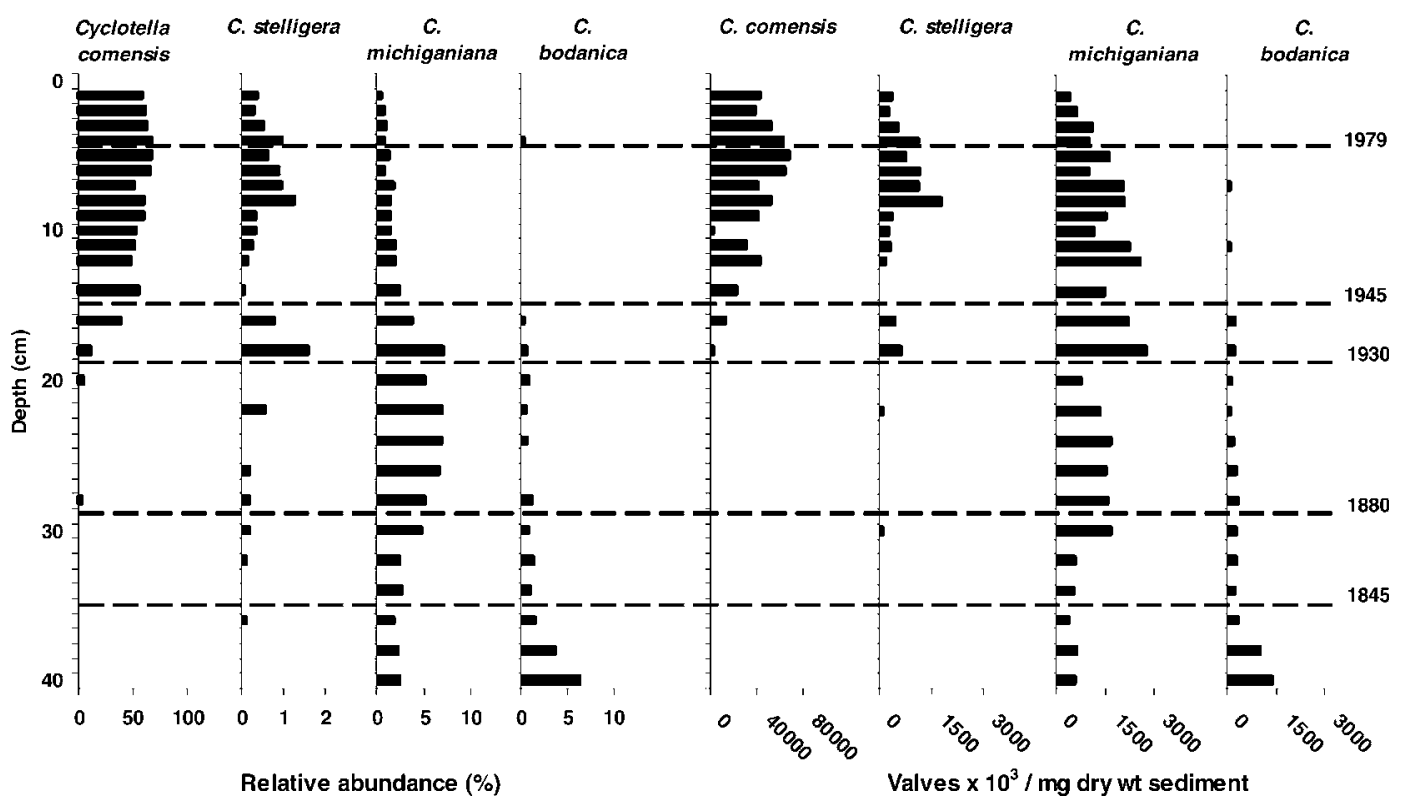

Figure 8. Relative abundance (\%) and concentration (valves $\times 10^{3} / \mathrm{mg}$ dry wt sediment) of Cyclotella species present in Lower Herring Lake surface sediments $(0-40 \mathrm{~cm})$. 


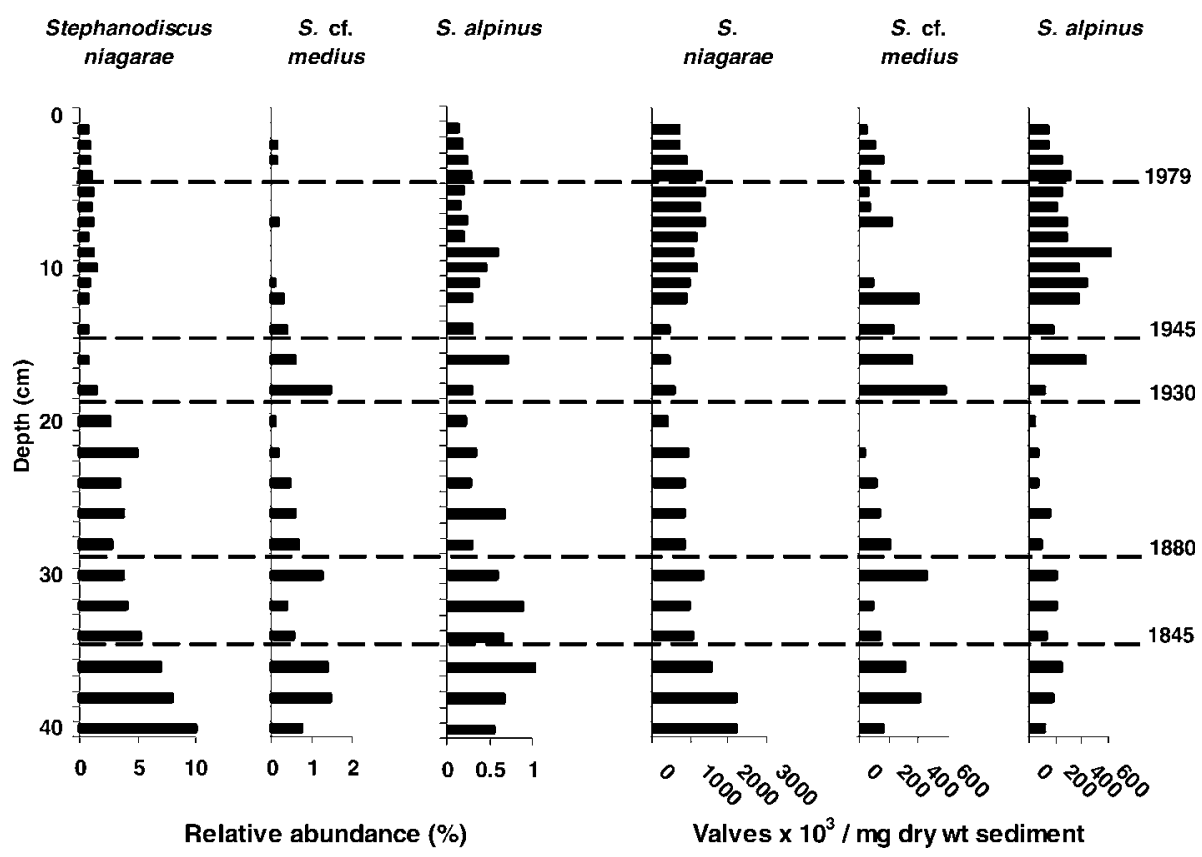

Figure 9. Relative abundance (\%) and concentration (valves $\times 10^{3} / \mathrm{mg}$ dry wt sediment) of Stephanodiscus species present in Lower Herring Lake surface sediments $(0-40 \mathrm{~cm})$.

explained by the first and second axes (82 and $89.5 \%$ respectively). Eigenvalues for the first, second and third axes are 0.5195, 0.0474, and 0.0203 , respectively. A plot of sample scores along the first and second axes (Figure 11) show a gradual shift from 40 to $20 \mathrm{~cm}$. Samples between 40 and $30 \mathrm{~cm}$ (pre-1845-1880s) occur in quadrant I, while samples 28-20 cm (ca. 1890s1929 ) occur in quadrant II. Diatom assemblages at 18 (ca. 1930) and $16 \mathrm{~cm}$ (ca. 1944) are distinct from other assemblages and samples above $14 \mathrm{~cm}$ (ca. 1945-1989) are found clustered around the first axis between quadrants III and IV. Removing $C$. comensis from the data (recalculating

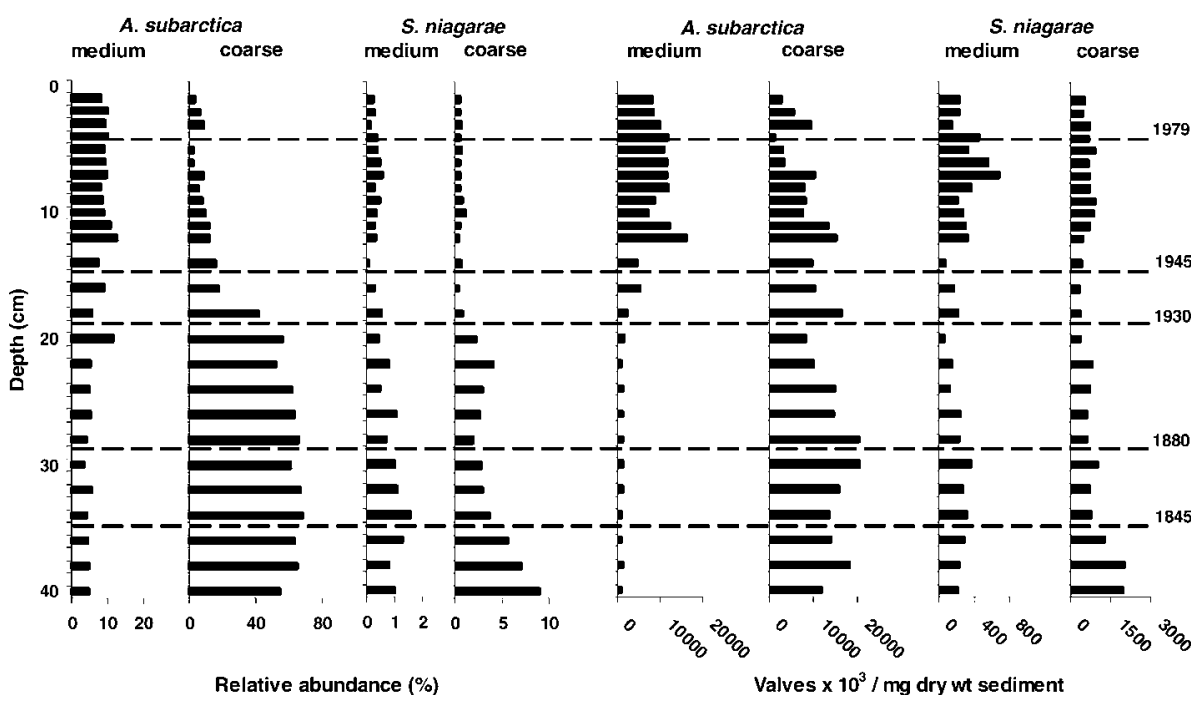

Figure 10. Relative abundance (\%) and concentration (valves $\times 10^{3} / \mathrm{mg}$ dry wt sediment) of morphological forms of Aulacoseira ambigua and Stephanodiscus niagarae in Lower Herring Lake surface sediments $(0-40 \mathrm{~cm})$. 


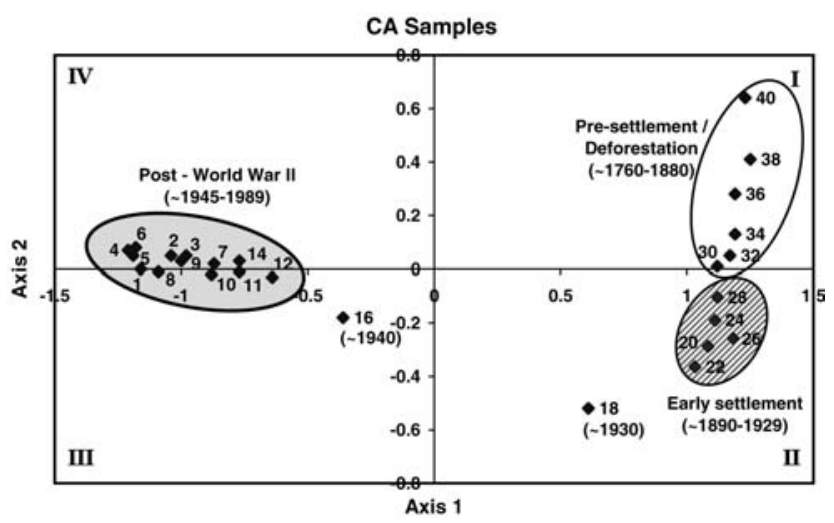

Figure 11. Correspondence analysis (CA) of samples based on relative abundance of major taxa ( $>1 \%$ and present in at least $50 \%$ of the samples) in Lower Herring Lake sediments $(40-0 \mathrm{~cm})$. Numbers correspond to sample depth in $\mathrm{cm}$.

percentages) yielded very similar results in ordination.

A plot of species scores along the first and second axes (Figure 12) indicate species assemblage associations by quadrant. Assemblages in quadrant I (pre- and early settlement period) include A. distans, A. subarctica, C. bodanica, S. cf. medius, $S$. niagarae and $T$. flocculosa, while Cyclotella michiganiana, F. capucina and Staurosirella lapponica are associated with quadrant II (early settle- ment). Benthic taxa including $A$. perpusilla and other members of the Fragilariaceae ( $F$. vaucheriae Fragilariforma virescens, Pseudostaurosira brevistriata, Staurosira construens, S. pinnata) cluster around the central point of Axes 1 and 2. Asterionella formosa, C. stelligera, F. crotonensis, and Synedra filiformis define assemblages in quadrant III, while $C$. atomus, C. comensis and $C$. kützingiana are associated with quadrant IV along Axis 2 (post-WWII period).

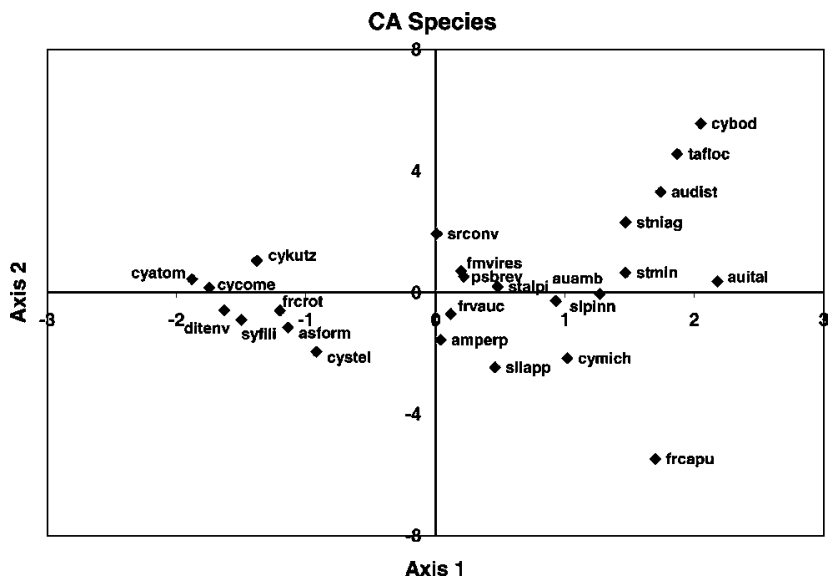

Figure 12. Correspondence analysis $(\mathrm{CA})$ of species data $(40-0 \mathrm{~cm})$ based on relative abundance of major taxa $(>1 \%)$. amperp $=$ Amphora perpusilla Grun., asform $=$ Asterionella formosa Hass., auambi $=$ Aulacoseira ambigua (Grun.) Simonsen, audist $=A$. distans (Ehrenb.) Simonsen, ausuba $=A$. subarctica (O. Müller) Haworth, cyatom $=$ Cyclotella atomus Hustedt, cyboda $=C$. bodanica Grun., cycome $=$ C. comensis Grun., cykutz $=$ C. kutzingiana Thwaites, cymich $=C$. michiganiana Skvortzow, cystel $=$ C. stelligera Cleve and Grunow, ditenv $=$ Diatoma tenue v. elongatum Lyngb., frcapu $=$ Fragilaria capucina Desm., frcrot $=F$. crotonensis Kitton, frvauc $=F$. vaucheriae (Kütz.) Peters, fmvire $=$ Fragilariforma virescens (Ralfs) Williams and Round, psbrev $=$ Pseudostaurosira brevistriata (Grun.) Williams and Round, srconv = Staurosira construens v. venter Ehrenb., sllapp $=$ Staurosirella lapponica (Grun. in Van Heurck) Williams and Round, slpinn $=S$. pinnata (Ehrenb.) Williams and Round, stalpin $=$ Stephanodiscus alpinus Hustedt, stminu $=S$. cf. medius, stniag $=S$. niagarae Ehrenb., syfili $=$ Synedra filiformis Grun., tafloc = Tabellaria flocculosa (Roth) Kütz. 
Historic trends of diatom-inferred TP (DI-TP) using optima from Fritz et al. (1993) closely followed profiles reported in their paper. Concentrations were highest in the lower sediments (40$20 \mathrm{~cm}$ ) and DI-TP trends ranged from $\sim 13.4$ to $12.6 \mu \mathrm{g} \mathrm{l}^{-1}$. DI-TP showed a declining trend between $18 \mathrm{~cm}\left(\sim 11 \mu \mathrm{g} \mathrm{1^{-1 }}\right)$ and $14 \mathrm{~cm}\left(\sim 8.5 \mu \mathrm{g} 1^{-1}\right.$ DI-TP), remained around 7-6 $\mu \mathrm{g}^{-1}$ DI-TP and increased slightly in the surface sediments ( $\sim 7.3 \mu \mathrm{g} 1^{-1}$ DI-TP, $\left.3-0 \mathrm{~cm}\right)$. Trends using optima from Reavie and Smol (2001) resulted in slightly higher DI-TP concentrations from $\sim 14.7$ to $10.3 \mu \mathrm{g} \mathrm{l}^{-1}$ DI-TP and showed similar, though less dramatic declines in the upper part of the core. Diatom-inferred TN (DI-TN) trends (optima from Reavie and Smol 2001) showed a similar pattern with higher concentrations ( $465 \mu \mathrm{g} \mathrm{1^{-1 }}$ DI-TN) from 40 to $20 \mathrm{~cm}$, declining to $\sim 420 \mu \mathrm{g} 1^{-1}$ DI-TN in the upper sediments $(14-4 \mathrm{~cm})$ before increasing slightly $\left(\sim 424 \mu \mathrm{g}^{-1}\right.$ DI-TN), at the surface (3$0 \mathrm{~cm}$ ). Concentrations for DI-TP and DI-TN were re-calculated by removing $C$. comensis from the data base. Trends in TP and TN from these data showed little change since European settlement. Total P optima (TPopt) used in the discussion for individual taxa are derived from both data sets and TN optima (TNopt) are from Reavie and Smol (2001).

\section{Discussion}

Sediment deposition in lakes during post-European settlement in North America is influenced by a variety of factors. The anthropogenic effects of deforestation, agriculture, and nutrient enrichment via sewage and phosphorus detergents result in increased deposition (e.g., Engstrom et al. 1985; Stoermer et al. 1985b, 1990). Additionally, signals may be muted or disturbed through processes of sediment compaction, dissolution, or re-suspension of surficial sediments.

\section{Geochemical signals}

Anthropogenic impact on the Herring Lake basin began sometime ca. 1845 AD with deforestation (Glarum 1983). The fine-grained sediment fraction displays higher $\phi_{50}$ values in this post-settlement section $(0-36 \mathrm{~cm})$, a reflection of anthropogenic influences. Warwick (1980) reported a progressive increase in fine-grained sediments as a result of increased land development by Europeans in the Bay of Quinte watershed. Major periods of disturbance in Lower Herring Lake, such as deforestation, can likewise be identified by increases in fine-particle sediments.

The sedimentary signal of deforestation is seen at 35-34 cm (ca. 1845-1850) as major influxes of coarser-grained sediments occur (Figure 4). This signal was used as a recent stratigraphic mark since it provides a better time constraint than ${ }^{210} \mathrm{~Pb}$ data, which is increasingly unreliable beyond 100 years. The concurrent increases in sand concentrations, coarser $\phi_{50}$, and a peak in the 38$63 \mu \mathrm{m}$ fraction all signal disturbances in the basin. Additional anthropogenic influences are indicated by coarser $\phi_{50}$ values at 28 and $27 \mathrm{~cm}$ (ca. 18921898). During this time, a shingle and saw mill were in operation along the southern end of Lower Herring Lake and wastes from these operations were disposed of in the lake. Additional settlement activity resulting in increased soil erosion is reflected in finer $\phi_{50}$ values between 27 and $25 \mathrm{~cm}$ (ca. 1898-1908). During this early period, Lower Herring Lake acts as a sediment trap for incoming materials from the surrounding basin.

Geochemistry data during deforestation and early settlement $(35-25 \mathrm{~cm})$ primarily reflect nutrient changes in the lake (Engstrom and Wright 1984). Sediment accumulation increases slightly between 35 and $32 \mathrm{~cm}$ (ca. 1845-1866) then increases again between 31 and $25 \mathrm{~cm}$ (ca. 1877-1903) before leveling off at 24-20 cm (ca. 1906-1929) (Figure 2c). Low accumulation rates of biogenic silica between 36 and $32 \mathrm{~cm}$ indicate baseline concentrations prior to heavy nutrient enrichment. A slight increase in accumulations of organic matter $(36-31 \mathrm{~cm})$ precede an increase in biogenic silica $(30-24 \mathrm{~cm})$ and reflects inputs from lumbering operations in the basin and a corresponding response of increased diatom deposition as nutrient inputs stimulate production. The gradual increase in carbonate accumulations $(32-18 \mathrm{~cm})$ also points to increased primary production after settlement. Increased carbonate precipitation is common in lakes of this region when higher primary production results in epilimnetic $\mathrm{CO}_{2}$ removal. Similar patterns were evident in nearby Intermediate Lake (Fritz et al. 1993). 
Sediment accumulation rates and geochemical profiles indicate that Lower Herring Lake is responding to anthropogenic activities in the basin through increased internal productivity between the late 1800s and early 1940s.

Carbonate and biogenic silica accumulations show a slight increase from 19 to $17 \mathrm{~cm}$ (early 1930s-late 1930s) and infer a rise in diatom and primary production. An additional increase in productivity is inferred from geochemical accumulations beginning at $13 \mathrm{~cm}$ (ca. 1957), and corresponds to a period of accelerated settlement in the lake basin. Additional evidence for increased settlement is seen in high concentrations of carbon fragments present between $16 \mathrm{~cm}$ and the surface (ca. 1940-1989, Wolin 1992). Increases in human activity can be identified by greater soot deposition that results from wood heat use and fossil fuel consumption (Renberg and Wik 1985). Michigan DNR records indicate that between 1955 and 1989 the number of cottages around Lower Herring Lake increased from ca. 50 to 150. Post-World War II cottage development and the introduction of phosphate detergents in the late 1940s resulted in higher nutrient input and greater anthropogenic influence in Lower Herring Lake basin.

The model presented in Schelske et al. (1983) predicts that increased phosphorus loadings result in greater diatom production and greater silica deposition. This results in a permanent loss of biologically available Si through sediment burial. Biogenic silica profiles from Lower Herring Lake indicate that increased silica deposition began shortly before 1940 and has continued. Although a slight decline may be present at the surface, the profile indicates that silica depletion has not yet occurred. Similar profiles have been found in sediments from Lakes Huron and Superior (Stoermer et al. 1985a; Wolin et al. 1988) where summer epilimnetic silica levels are not yet limiting to diatom growth. A corresponding increase in accumulation rates beginning ca. $12 \mathrm{~cm}$ (1960) primarily results from silica deposition and recent increases in organic matter (Figure 3). Beginning in the 1940s, Lower Herring Lake acts as a biogeochemical processor of nutrients and a sink for available $\mathrm{Si}$. Increased primary production stimulated by nutrient loadings to the basin result in increased sediment deposition of organic carbon. Sediment deposition of nitrogen and phosphorus has also been shown to increase with primary production. In their study of shoreline development in four Wisconsin lakes, Garrison and Wakeman (2000) showed that increases in nitrogen and phosphorus content of sediments were associated with organic carbon accumulation. Additionally, the increase in diatom production has accelerated biogenic silica deposition, permanently removing some of the available $\mathrm{Si}$ from the lake.

Sediments above $4 \mathrm{~cm}$ are too recent to provide any more than speculative information. These upper sediments are still subject to bioturbation and mixing and most likely do not yet represent the permanent sediment record of Lower Herring Lake. However a leveling off in biogenic silica and carbonate accumulation rates may reflect a response of phytoplankton to phosphorus controls and phosphate detergent bans in the Great Lakes basin (Stoermer et al. 1985b; Schelske 1991; Wolin et al. 1991).

\section{Microfossil signals}

Pre- and early settlement microfossil assemblages are represented in samples $40-20 \mathrm{~cm}$ (pre-18451929). These assemblages are dominated by Aulacoseira ambigua (60-75\%) and include A.subarctica, Cyclotella bodanica, C. michiganiana, Fragilaria crotonensis, Stephanodiscus alpinus, $S$. cf. medius, S. niagarae and Tabellaria flocculosa. The dominance of Aulacoseira ambigua suggests a prevalence of turbulent conditions in Lower Herring Lake. These diatoms rely on mixing and turbulence to remain suspended in the water column. Bradbury et al. (2002) reported increases of A. ambigua in Elk Lake, MN after deforestation. The sediment record of Lower Herring Lake, however, shows this species is a dominant component of the diatom flora since the lake was isolated (Wolin 1996). Results of CA (Figure 11) indicate a gradual shift in assemblages from the pre-settlement/deforestation (pre-1845-1880s, quadrant I) to early post-settlement period (1890s1929, quadrant II).

Cyclotella bodanica and Tabellaria flocculosa are present in the pre-settlement period. They decline during post-settlement in an apparent response to increased nutrient loadings. These two species (Figures 6 and 8) decline rapidly after deforestation and only represent a minor percentage in 
assemblages above $16 \mathrm{~cm}$ (1944). Total P and TN optima (TPopt, TNopt) for these species are relatively low compared to taxa from more recent sediments $\quad$ (TPopt $=9-13 \mu \mathrm{g} 1^{-1}$, TNopt $=$ $410 \mu \mathrm{g} \mathrm{l}^{-1}$ for $T$. flocculosa and TPopt $=11-$ $14 \mu \mathrm{g} \mathrm{1^{-1 }}$, TNopt $=382 \mu \mathrm{g} \mathrm{l^{-1 }}$ for C. bodanica). Cyclotella bodanica is a widespread eurytopic species, common in summer flora of the upper Great Lakes particularly Lakes Superior and Huron (Barbiero and Tuchman 2001a). Its decline in Lower Herring Lake sediments may result from increased nutrient competition with $C$. michiganiana which has a higher TN optimum $\left(426 \mu \mathrm{g} \mathrm{l}^{-1}\right)$ and increases between 30 and $20 \mathrm{~cm}$ (1890s-1929). This same pattern of succession from C.bodanica to C. michiganiana was reported in Moose Lake, Wisconsin and attributed to early nutrient increases following initial lakeshore development (Garrison and Wakeman 2000). Percent abundance of Stephanodiscus alpinus (TPopt $=9$ $13 \mu \mathrm{g} 1^{-1}$, TNopt $=530 \mu \mathrm{g}^{-1}$ ) also increases between 36 and $30 \mathrm{~cm}$ (Figure 9) providing additional evidence of nutrient increases. These diatom-inferred nutrient changes, species shifts and increases in total microfossil concentration indicate that Lower Herring Lake is acting as a biological processor and nutrient sink during deforestation and early settlement (ca. 1845-1880).

A change in assemblages results from increased abundances of Aulacoseira subarctica (Figure 11), Cyclotella michiganiana, F. capucina, Asterionella formosa and $F$. crotonensis during the early postsettlement period (ca. 1880-1929). Cyclotella comensis and $C$. stelligera also begin to increase and $F$. capucina, described by Stoermer (1993) as one of the reliable indicators of eutrophication in the Great Lakes, increases noticeably and reaches its highest percent abundance in this section. Reported TPopt and TNopt for F. capucina are 27 and $554 \mu \mathrm{g} 1^{-1}$, respectively.

The increases in Aulacoseira subarctica, A. formosa and $F$. crotonensis between 30 and $20 \mathrm{~cm}$ (ca. 1880-1929) most likely are a response to changing nutrient conditions. Published TP optima for these taxa are similar to flora of the pre-settlement/ deforestation period, however, TN optima are higher (455, 423 and $437 \mu \mathrm{g} 1^{-1}$, respectively). In their now classic experiment on Hubbard Brook, Likens et al. (1970) showed that elevated nitrogen inputs from the catchment occurred for an extended period following deforestation. We can expect a similar response in the Herring Lake basin. Asterionella formosa and $F$. crotonensis are commonly used to infer increased nutrient loadings and both have been considered indicators of anthropogenic disturbance (e.g., Fritz et al. 1993; Garrison and Wakeman 2000; Forrest et al. 2002). Increases in $A$. formosa are commonly found in recent Great Lakes sediments where nutrient enrichment from anthropogenic sources occurs (e.g., Stoermer et al. 1985a, 1990, 1991; Wolin et al. 1988, 1991) and the distribution and increased abundance of Fragilaria crotonensis is indicative of rising nitrate concentrations (Stoermer et al. 1978; Wolin et al. 1991).

Cyclotella michiganiana, C. comensis, C. stelligera and $F$. crotonensis are all found in summer plankton of the Great Lakes (Stoermer and Yang 1970; Barbiero and Tuchman 2001a) and have been reported as components of the deep chlorophyll maxima (DCM) (Stoermer and Kreis 1980; Fahnenstiel and Glime 1983; Fahnenstiel and Scavia 1987). Barbiero and Tuchman (2001b) found that $F$. crotonensis was a common part of the DCM during August 1998 in Lakes Superior, Huron and Ontario as was $C$. comensis in Lake Michigan. Carrick (2004) also reported F. crotonensis and C. comensis as components of the subsurface maximum in the central basin of Lake Erie. The occurrence and increased abundance of these taxa in Lower Herring Lake infer an increase in epilimnetic productivity or greater development of a DCM during the early post-settlement period (ca. 1882-1920) and overall microfossil evidence indicates that biological processes in Lower Herring Lake are responding to nutrient loadings, particularly nitrogen, as human activity increases in the catchment.

A transition in assemblages occurs between ca. 1930s and early 1940s (18-16 cm). Microfossil and sedimentary evidence indicate Lower Herring Lake experienced low-lake levels during the 1930s (Wolin 1992). These conditions most likely increased nutrient concentrations and may have poised the lake for a permanent shift in flora once anthropogenic disturbances increased from accelerated shoreline development in the late 1940s. The overall decline in percentage of chrysophycean cysts (Figure 5) points to increased nutrient enrichment of the lake (Smol 1985). Correspondence analysis (Figure 11) places assemblages at 18 and $16 \mathrm{~cm}$ in quadrants II and III, between those 
of the pre-settlement/early post-settlement period (ca. 1845-1929) and the post-WWII period (ca. 1940s-1989).

Asterionella formosa, Fragilaria crotonensis continue to increase during this period and Diatoma tenue v. elongatum first appears. Diatoma tenue v. elongatum is common in eutrophied areas of the Great Lakes and indicative of high conservative ion loadings. $\mathrm{Cl}$ optima of $81.8 \mathrm{meq} 1^{-1}$ were reported for this taxon by Ramstack et al. (2003). Their study also showed historic $\mathrm{Cl}$ increases were primarily associated with anthropogenic impact on lakes in the Minneapolis - St Paul metropolitan region. Presence of this diatom in Lower Herring Lake could, in part, be related to use of water softening agents by residents around the lake.

A continued increased in epilimnetic productivity during summer stratification is inferred by increased percentages of summer blooming taxa. Cyclotella michiganiana and $C$. stelligera reach their highest percentages during this transition and Cyclotella comensis quickly increases to become the dominant taxon in the core. Increases in Stephanodiscus alpinus (TPopt $=19 \mu \mathrm{g} \mathrm{l}^{-1}$, TNopt $=530 \mu \mathrm{g}^{-1}$ ) and $S$. cf. medius (TPopt $=$ $16 \mu \mathrm{g}^{-1}$, TNopt $=456 \mu \mathrm{g}^{-1}$ ) occur and may be a response increased nutrient loadings during spring mixing. Aulacoseira ambigua profiles reflect a decline in percent abundances as anthropogenic enrichment increases, although valve concentrations in the core remain nearly constant. The continued presence of $A$. ambigua throughout the core reflects the prevalence of turbulent conditions in the lake. Lower Herring Lake is frequently exposed to winds coming off Lake Michigan and mixing episodes occur even during the summer stratification period.

Post-World War II microfossil assemblages are represented in samples $14-1 \mathrm{~cm}$ (ca. 1940s-1989). Correspondence analysis (Figure 11) places these assemblages along Axis 1 in quadrants III and IV and CA of the species data (Figure 12) indicates that these assemblages are associated with abundances of $A$. formosa, C. atomus, C. comensis, C. kützinginana, D. tenue v. elongatum, F. crotonensis, and S. filiformis. Microfossils are dominated by diatoms and concentrations increase more than twofold above $14 \mathrm{~cm}$. A decrease in relative abundance of chrysophycean cysts occurs, although actual numbers increase slightly over pre- vious samples. A similar increase in microfossil abundance was reported in sediments from Green Bay around the same time (ca. 1938, Stoermer et al. 1991). In a nearby sediment profile from northern Lake Michigan, however, this increased accumulation does not occur until the early 1960s (Stoermer et al. 1990). The delayed effect of this signal is primarily size and depth dependent. Northern Lake Michigan experienced silica depletion later than the southern basin owing to higher dissolved silica reserves in the deeper waters (Schelske 1988). Historically, shallow regions and nearshore areas (such as Green Bay) experienced silica depletion sooner than the open lake. Additionally, marginal bays and lakes such as Lower Herring were the primary recipients of catchment nutrient loads, often acting as nutrient sinks, thereby reducing initial anthropogenic impacts to Lake Michigan.

Assemblages above $14 \mathrm{~cm}$ (1953) are dominated by Cyclotella comensis (49-67\%). Other significant taxa in this section include Aulacoseira ambigua, C. stelligera, C. michiganiana, Diatoma tenue v. elongatum, Stephanodiscus alpinus, S. cf. medius and $S$. niagarae. These latter taxa decline in percent abundance while actual numbers increase indicating an overall increase in productivity.

Anthropogenic disturbance indicators, Asterionella formosa (TNopt $=423 \mu \mathrm{g}^{-1}$ ) and Diatoma tenue v. elongatum, continue to increase after 1944. Both of these taxa decline above $5 \mathrm{~cm}$ (1979) while Fragilaria crotonensis (TNopt $=437 \mu \mathrm{g} \mathrm{l}^{-1}$ ) increases. Fragilaria crotonensis was dominant to common in the 1986 flora of Lower Herring Lake during summer stratification (June-August). Overall trends in DI-TN increased slightly in the surface $(3-0 \mathrm{~cm})$ and the increased abundance of $F$. crotonensis in these sediments coincides with higher nitrogen concentrations reported from the Great Lakes during the 1980s (Stevens and Nielson 1987).

Declines in Cyclotella bodanica and C. michiganiana above $14 \mathrm{~cm}$ correspond to the increasing dominance of $C$. comensis in the summer flora, and most likely reflect loss from increased competition. The increased abundance of $C$. stelligera $(\mathrm{DI}-\mathrm{TP}=$ $11 \mu \mathrm{g}^{-1}$ ) infers nutrient concentrations are increasing in Lower Herring Lake. This planktonic Cyclotella is common in oligo-mesotrophic regions of the Great Lakes area and has been shown to respond quickly to increases in phosphorus 
(Schelske et al. 1972, 1974, 1975; Schelske and Stoermer 1972). Peak abundance and concentration of this taxon occur in the upper portion of the core between 8 and $4 \mathrm{~cm}$ (ca. 1972-1982) and a corresponding peak in carbon fragment data at $8 \mathrm{~cm}$ (Wolin 1992) indicates the response in diatom data may be the result of catchment disturbance.

Abundance of Cyclotella comensis (Figure 8) increases dramatically at $14 \mathrm{~cm}$ (1953), before leveling off. This taxon and its morphotypes are common in recent flora of the area (Ontario region, Forrest et al. 2002; Reavie and Smol 2001; and northern lower Michigan, Fritz et al. 1993). Fritz et al. (1993) indicate this C. comensis-complex is a common component of the post-settlement flora, exhibiting large increases in concentration during the 1950s and 1960s. Forrest et al. (2002) report similar increases in lakes along the Rideau Canal system in Ontario after 1950. Core profiles from the upper Great Lakes show rapid increases in $C$. comensis abundance after a prolonged period of occasional occurrences following European settlement (Stoermer et al. 1985a, 1990, 1993; Wolin et al. 1988). These increases are seen in Lake Huron and Superior sediments after 1946 (Stoermer et al. 1985a; Wolin et al. 1988) and maximum percentages in Lake Michigan sediments occur after 1964 (Stoermer et al. 1990). This taxon also appears post-European settlement in Lower Herring Lake. Stoermer $(1993,1998)$ has suggested it may be an early nonnative introduction from Europe. Cyclotella comensis commonly occurs in northern European lakes, particularly in eastern Germany (Wolin unpublished data) and it has been correlated with summer temperature optima in Swiss lakes (Hausmann and Lotter 2001).

We found Cyclotella comensis problematic in determining trends in DI-TP as did Fritz et al. (1993). It dominates assemblages above $14 \mathrm{~cm}$ and DI-TP trends decline while the presence of other taxa and increased microfossil concentrations appear to indicate otherwise. Fritz et al. (1993) indicate that DI-TP phosphorus reconstruction anomalies may result from phosphorus optima of the taxa that do not adequately describe the 42 lake data set. We believe that this is probably true, at least for optimum determined for $C$. comensis. The training sets published in Fritz et al. (1993) use summer epilimnetic concentrations in determining the nutrient optima for $C$. comensis and, while Reavie and Smol (2001) use optima from May and late August/early September, both papers have probably underestimated the TP optimum for this species. We believe that these measurements do not take into account the true ecological optimum of this taxon. Experimental results from early nutrient enrichment experiments indicate this species responds rapidly to phosphorus increases (Schelske et al. 1972), however it is not tolerant of severely eutrophied conditions (Stoermer et al. 1985b). Additionally, Stoermer and Kreis (1980) reported that abundance of $C$. comensis in Lake Huron was associated with high nitrate levels and that it appeared to be efficient in silica utilization. Forrest et al. (2002) reported that $C$. comensis was associated with increased stratification and lake depth and Hausmann and Lotter (2001) found thermal relationships between $C$. comensis and summer temperature optima. As mentioned previously, this taxon is a summer blooming species and is frequently found in the DCM of the Great Lakes. The DCM occurs in stratified lakes with low epilimnetic nutrient concentrations and high light penetration. While low TP conditions in the epilimnion contribute to light conditions that allow C. comensis to exploit nutrients in the metalimnion, they do not represent optima for its growth. Fritz et al. (1993) used summer epilimnetic TP concentrations of $5 \mu \mathrm{g} 1^{-1}$ from Lower Herring Lake in their data set. However, monthly data collected by the primary author in 1986 indicates that TP values during spring and fall mixing measured 31 and $42.5 \mu \mathrm{g} 1^{-1}$, respectively. These values indicate that higher concentrations of TP are most likely available to $C$. comensis at the DCM. Recent data from annual surveys in the Great Lakes (Barbiero and Tuchman 2001a) indicate $C$. comensis is an important component in spring surface waters of Lake Erie where total soluble phosphorus (TSP) values vary from 3 to $12 \mu \mathrm{g} \mathrm{l}^{-1}$ and $\mathrm{NO}_{3}$ from 250 to $>750 \mu \mathrm{g} \mathrm{l}^{-1}$. Detrended correspondence analysis indicates the Lake Erie spring assemblages are positively correlated with TSP concentrations and negatively associated with $\mathrm{Si}$ concentrations. Lake Erie summer diatom communities have recently been dominated by small Cyclotella species (mean \# cells $1^{-1}=760$ western; 2110 central and 855 eastern basins) and although summer TSP and $\mathrm{NO}_{3}$ levels are much lower (1-3 and $\pm 250 \mu \mathrm{g}^{-1}$, 
respectively) release of nutrients from the sediments frequently occur due to wind-driven mixing in the shallow western and central basins. We believe that the dominance of $C$. comensis in Lower Herring Lake may be a response to increased nitrogen inputs as well as a competitive response to changes in epilimnetic Si:P ratios (e.g., Tilman et al. 1982).

Aulacoseira ambigua and Stephanodiscus species concentrations also decline as anthropogenic enrichment increases (Figures 7 and 9). In the post-WWII period (ca. 1953-1989), Stephanodiscus species comprise ca. $1-2 \%$ of the population, Stephanodiscus niagarae being the most common. Species present in the modern flora are common in late-winter early-spring phytoplankton associations. Monthly sampling in 1986 indicated S. niagarae was dominant to common in a spring phytoplankton (April-May) and again during fall mixing periods (October-November). It occurs over a wide range of trophic conditions. Evidence suggests that eutrophic conditions may actually limit production and that under severely eutrophic conditions, sexual reproduction may cease (Stoermer et al. 1989; Julius et al. 1998).

Distributions of Stephanodiscus cf. medius in early post-settlement sediments and its occurrence in lower sections of the core (Wolin 1996), imply oligo-mesotrophic requirements. Its profile corresponds closely to that of Cyclotella stelligera and, by inference, it appears to be a winter-spring blooming form which responds to higher $\mathrm{P}$ concentrations. In Lower Herring Lake, concentrations of $S$. cf. medius increase during disturbance and transitional periods $(18-16$ and $7 \mathrm{~cm})$.

Silica-related morphological changes in A. ambigua and $S$. niagarae were also evident in Lower Herring Lake sediments. Stoermer et al. $(1985 \mathrm{c})$ reported that changes in silicification of A. islandica in Lake Ontario sediments reflected changes in water column $\mathrm{Si}$ concentrations. As $\mathrm{Si}$ concentrations decreased with time, these species produced a greater percentage of lightly silicified valves. Morphological changes in response to changing silica concentrations have also been demonstrated in Stephanodiscus niagarae and S. alpinus (Stoermer et al. 1985b; Theriot 1987; Theriot et al. 1988; Stoermer et al. 1989). Concentration and abundance data show a similar pattern in Lower Herring Lake (Figure 10). Changes in Aulacoseira ambigua valve morphology indicate that $\mathrm{Si}$ concentrations have declined since ca. $1944(16 \mathrm{~cm})$, and a corresponding increase in sediment accumulation of biogenic silica (Figure 3) supports this interpretation. Stephanodiscus niagarae also undergoes morphological change in response to changing silica concentrations. Profiles of $S$. niagarae concentrations (Figure 9) indicate increased accumulation in post-WWII sediments and highest abundances since deforestation. Morphological evidence implies that this increase may result from a shift to populations more readily adapted to the increasing nutrient conditions of Lower Herring Lake. Morphological profiles of S. niagarae (Figure 10) show an increase in percentage and concentration of medium thickness valves above $12 \mathrm{~cm}$ (ca. 1961). The continued presence of coarsely silicified valves and absence of finely silicified valves such as those found in Lake Ontario sediments indicate Lower Herring Lake has not yet reached the epilimnetic silica depletion stage. Additionally, the presence of 'oligotrophic' summer Cyclotella flora in sediments indicate adequate $\mathrm{Si}$ supplies exist during summer stratification (Stoermer 1993). Present day Si concentrations still appear to be high enough to support abundant diatom populations. Due to frequent turbulent conditions, nutrients are more readily available here than in other lakes which may undergo $\mathrm{Si}$ depletion in the epilimnion. Monthly sampling in 1986 indicated that epilimnetic Si concentrations dropped to $0.94-1.5 \mathrm{mg}^{-1}$ in June and July. Although not limiting for diatom growth, these measurements show a large decrease from turnover concentrations of $9.2 \mathrm{mg}^{-1}$ in April and indicate that intensive $\mathrm{Si}$ assimilation is occurring.

Anthropogenic activity during the post-WWII period in Lower Herring Lake is characterized by increased shoreline development and nutrient increases from surrounding cottages. Shifts in the microfossil and geochemical record indicate the lake is acting as a biological processor and a nutrient and carbon sink as productivity increases. Additionally, the increase in diatom productivity results in a permanent loss of silica to the lake sediments.

Biogenic silica accumulation levels off in the upper $4 \mathrm{~cm}$ and a decline in the abundance of C. comensis occurs. This is in contrast to an increase in $F$. crotonensis and may be a response to decreased TP loads resulting from phosphate 
reductions that began in the 1970s. Fragilaria crotonensis is an excellent competitor for phosphorus (Kilham and Kilham 1978) and can thrive at higher Si:P ratios. Additional support for reduced TP concentrations is found in the reoccurrence of low TPopt taxa such as $A$. subarctica and $T$. flocculosa in these upper sediments.

\section{Conclusions}

The paleorecord indicates Lower Herring Lake has been an oligo-mesotrophic lake for much of its history (Wolin 1996). Several signals of lake development are present. However, the most recent and perhaps most dramatic is that of anthropogenic influences in the catchment. A deforestation signal was evident in increased sand concentrations and coarser grain-size distributions followed by an influx of fine-grained sediments resulting from soil erosion. An initial nutrient response in the microfossil assemblage corresponds to this signal followed by an apparent recovery between ca. 1866 and 1900 (32-26 cm).

Significant changes did not occur in Lower Herring Lake until ca. 1930s. Increased nutrient enrichment effects, reflected in geochemical profiles (organic carbon and biogenic silica accumulations) and sediment accumulation data, begin ca. 1944. Increases in microfossil accumulation (and loss of biogenic Si) occur earlier ca. $1930(20 \mathrm{~cm})$, but accelerate dramatically after ca. 1944. Anthropogenic impacts have not only increased phytoplankton production, but greatly altered the diatom assemblages present. Although still considered mesotrophic, there has been a shift in dominant summer flora since ca. 1944. Large increases in the Cyclotella comensis-complex have replaced other Cyclotella species formerly occupying this niche. In general, the oligo-mesotrophic summer flora has been replaced by increased concentrations of eurytopic forms and species associated with increased nitrogen concentrations. Increased phosphorus loadings since the late 1940s have resulted in various stages of silica depletion in the Great Lakes system (Schelske et al. 1983, 1986). Morphological changes observed in species present in Lower Herring Lake sediments (Aulacoseira ambigua and Stephanodiscus niagarae) indicate that summer epilimnetic silica supplies have been reduced over the past 40 years but have not yet reached growth-limiting levels. Since the late 1940s, Lower Herring Lake has been a biogeochemical processor of nutrients and a sink for organic and inorganic carbon and biogenic $\mathrm{Si}$, reducing available inputs to nearby Lake Michigan.

Signals of nutrient enrichment similar to those found in Lower Herring Lake have been found in other lakes in the region (Fritz et al. 1993). These signals occur between ca. 1930s and 1950s. In Green Bay, Wisconsin, microfossil abundance increases and species shifts occur ca. 1940 (Stoermer et al. 1991). A comparison of these anthropogenic signals and those of Lower Herring Lake with Lake Michigan data show a lag-time of approximately $20-25$ years.

It appears that marginal lakes such as Lower Herring Lake and bays can act as buffering systems, delaying the effects of anthropogenic nutrient inputs on Lake Michigan. Additionally, due to its large size, initial impacts to Lake Michigan are relatively minor. However, once inland systems are pushed past a threshold point, outflow from tributaries and marginal lakes such as Lower Herring Lake transport these changes into Lake Michigan. Initial signals of nutrient enrichment are first seen in nearshore areas and then translated across the entire lake as inputs continue. Cyclotella comensis may well be a stratigraphic marker for evidence of this process. This ubiquitous species, common to dominant in inland lakes beginning ca. 1930, is rare in surficial microfossil data of Lake Michigan from 1983 (Stoermer et al. 1990). However, recent surveys on the Great Lakes indicate it has become well established in present day assemblages and presently is a common component of the Lake Erie summer flora (Barbiero and Tuchman 2001a; Carrick et al. 2001; Carrick 2004).

\section{Acknowledgements}

Initial sediment work was supported by Michigan Sea Grant College Program Grant \# NA89AA-DSG083. Special thanks to C.L. Schelske for providing ${ }^{210} \mathrm{~Pb}$ dates and Owen Lockhart for preparing the site location map. Land-use history and additional limnological information was provided by S. Glarum, S. Fritz and the Michigan 
DNR. Thanks to John Smol and two anonymous reviewers who provided useful comments for improvements to the original manuscript.

\section{References}

Appleby P.G. and Oldfield F. 1983. The assessment of ${ }^{210} \mathrm{~Pb}$ data from sites with varying sediment accumulation rates. Hydrobiologia 103: 29-35.

Appleby P.G., Nolan P.J., Gifford D.W., Godfrey M.J., Oldfield F., Anderson N.J. and Battarbee R.W. $1986 .{ }^{210} \mathrm{~Pb}$ dating by low background gamma counting. Hydrobiologia 143: 21-27.

Barbiero R.P. and Tuchman M.L. 2001a. Results from the US EPA's biological open water surveillance program of the Laurentian Great Lakes: I. Introduction and phytoplankton results. J. Great Lakes Res. 27: 134-154.

Barbiero R.P. and Tuchman M.L. 2001b. Results from the US EPA's biological open water surveillance program of the Laurentian Great Lakes: II Deep chlorophyll maxima. J. Great Lakes Res. 27: 155-166.

Baron J.S., Poff N.L.R., Angermeier P.L., Dahm C.N., Gleick P.H., Hairston N.G.Jr., Jackson R.B., Johnston C.A., Richter B.D. and Steinman A.D. 2002. Meeting ecological and societal needs for freshwater. Ecol. Appl. 12: 1247-1260.

Battarbee R.W. 1973. A new method for the estimation of absolute microfossil numbers, with reference especially to diatoms. Limnol. Oceanogr. 18: 647-653.

Bradbury J.P., Cumming B. and Laird K. 2002. A 1500-year record of climatic and environmental change in Elk Lake, Minnesota III: measures of past primary productivity. J. Paleolimnol. 27: 321-340.

Carrick H. 2004. Algal distribution patterns in Lake Erie: implications for oxygen balances in the eastern basin. $\mathrm{J}$. Great Lakes Res. 30: 133-147.

Carrick H., Barbiero R.P. and Tuchman M. 2001. Variation in Lake Michigan plankton: temporal, spatial and historical trends. J. Great Lakes Res. 27: 467-485.

Conley D.J. 2000. Biochemical nutrient cycles and nutrient management strategies. Hydrobiologia 410: 87-96.

Conley D.J., Schelske C.L. and Stoermer E.F. 1993. Modification of the biogeochemical cycle of silica with eutrophication. Mar. Ecol. Prog. Ser. 101: 179-192.

Davis C.O. and Simmons M.S. 1979. Water chemistry and phytoplankton field and laboratory procedures. University of Michigan, Great Lakes Research Division Special Report 70, pp. 1-73.

DeMaster D.J. 1979 The marine budgets of silica and ${ }^{32} \mathrm{Si}$. PhD thesis, Yale University, New Haven, Conn., 308 pp.

DeMaster D.J. 1981. The supply and accumulation of silica in the marine environment. Geoch. Cosmoch. Acta 45: 17151732.

Dean W.R.Jr. 1974. Determination of carbonate and organic matter in calcareous sedimentary rocks by loss on ignition: comparison with other methods. J. Sed. Petrol. 44: 242248.

Dixit S.S., Smol J.P., Charles D.F., Hughes R.M., Paulsen S.G. and Collins G.B. 1999. Assessing water quality changes in the lakes of the northeastern United States using sediment diatoms. Can. J. Fish. Aquat. Sci. 56: 131-152.

Earle J.C. and Duthie H.C. 1986. A multivariate statistical approach for interpreting marshland diatom succession. In: Proceeding of the 8th International Symposium on Living and Fossil Diatoms, Paris France, pp. 441-458.

Engstrom D.R. and Wright H.E.Jr. 1984. Chemical stratigraphy of lake sediments as a record of environmental change. In: Haworth E.Y. and Lund J.W.G. (eds), Lake Sediments and Environmental History. University of Minnesota Press, Minneapolis, pp. 11-67.

Engstrom D.R., Swain E.B. and Kingston J.C. 1985. A paleolimnological record of human disturbance from Harvey's Lake, Vermont: geochemistry, pigments and diatoms. Freshwat. Biol. 15: 261-288.

Fahnenstiel G.L. and Glime J.M. 1983. Subsurface chlorophyll maximum and associated Cyclotella pulse in Lake Superior. Int. Revue Ges. Hydrobiol. 68: 605-618.

Fahnenstiel G.L. and Scavia D. 1987. Dynamics of Lake Michigan phytoplankton: the deep chlorophyll layer. J. Great Lakes Res. 13: 285-295.

Folk R.L. 1974. Petrology of Sedimentary Rocks. Hemphill, Austin, Texas, $182 \mathrm{pp}$.

Forrest F., Reavie E.D. and Smol J.P. 2002. Comparing limnological changes associated with the 19th century canal construction and other catchment disturbances in four lakes within the Rideau Canal system Ontario, Canada. J. Limnol. 61: 183-197.

Fritz S.C., Kingston J.C. and Engstrom D.R. 1993. Quantitative trophic reconstruction from sedimentary diatom assemblages: a cautionary tale. Freshwat. Biol. 30: 1-23.

Garrison P.J. and Wakeman R.S. 2000. Use of paleolimnology to document the effect of lake shoreland development on water quality. J. Paleolimnol. 24: 369-393.

Glarum S.N. 1983. Our Land and Lakes. Benzie County, Lower Herring Lake. West Graf, J.B. Publications, Manistee, Michigan, $70 \mathrm{pp}$.

Glover R.M. 1982. Diatom fragmentation in Grand Traverse Bay, Lake Michigan and its implications for silica cycling. $\mathrm{PhD}$ thesis, University of Michigan, Ann Arbor, 204 pp.

Håkanson L. and Jansson M. 1983. Principles of Lake Sedimentology. Springer-Verlag, New York, 316 pp.

Håkansson H. and Kling H. 1990. The current status of some very small freshwater diatoms of the genera Stephanodiscus and Cyclostephanos. Diatom Res. 5: 273-287.

Hall R.I. and Smol J.P. 1999. Diatoms as indicators of lake eutrophication. In: Stoermer E.F. and Smol J.P. (eds), The Diatoms: Applications for the Environmental and Earth Sciences. Cambridge University Press, Cambridge, pp. 128-168.

Hausmann S. and Lotter A.F. 2001. Morphological variation within the diatom taxon Cyclotella comensis and its importance for quantitative temperature reconstructions. Freshwat. Biol. 46: 1323-1333.

Julius M.L., Stoermer E.F., Taylor C.M. and Schelske C.L. 1998. Local extirpation of Stephanodiscus niagarae (Bacillariophyceae) in the recent limnological record of Lake Ontario. J. Phycol. 34: 766-771.

Kilham P. and Kilham S.S. 1978. Natural community bioassays: predictions of results based on nutrient physiology and competition. Verh. Int. Ver. Limnol. 20: 68-74. 
Krausse G.L., Schelske C.L. and Davis C.O. 1983. Comparison of three wet-alkaline methods of digestion of biogenic silica in water. Freshwat. Biol. 13: 73-81.

Krieger K.A. 2003. Effectiveness of a coastal wetland in reducing pollution of a Laurentian Great Lake: hydrology, sediment, and nutrients. Wetlands 23: 778-791.

Likens G.E., Bormann F.H., Johnson N.M., Fisher D.W. and Pierce R.S. 1970. Effects of forest cutting and herbicide treatment on nutrient budgets in the Hubbard Brook watershed-ecosystem. Ecol. Mongr. 40: 23-47.

Patrick R.P. and Reimer C.W. 1966. The Diatoms of the United States, Vol I. Academy of Natural Sciences, Philadelphia, Monograph No 13, 688 pp.

Ramstack J.M., Fritz S.C., Engstrom D.R. and Heiskary S.A. 2003. The application of a diatom-based transfer function to evaluate regional water-quality trends in Minnesota since 1970. J. Paleolimnol. 29: 79-94.

Reavie E.D. and Smol J.P. 2001. Diatom-environmental relationships in 64 alkaline southeastern Ontario (Canada) lakes: a diatom-based model for water quality reconstruction. J. Paleolimnol. 25: 25-42.

Renberg I. and Wik M. 1985. Soot particle counting in recent sediments: an indirect dating method. Ecol. Bull. 37: 53-57.

Schelske C.L. 1988. Historic trends in Lake Michigan silica concentrations. Int. Revue Ges. Hydrobiol. 73: 559-591.

Schelske C.L. 1991. Historical nutrient enrichment of Lake Ontario: paleolimnological evidence. Can. J. Fish. Aquat. Sci. 48: 1529-1538.

Schelske C.L. and Stoermer E.F. 1972. Phosphorus, silica and eutrophication of Lake Michigan. In: Likens G.E. (ed), Nutrients and Eutrophication. Special Symposia, Vol. 1. American Society of Limnology and Oceanography, Allen Press Lawrence, Kansas, pp. 157-171.

Schelske C.L., Conley D.J., Stoermer E.F., Newberry T.J. and Cambell C.D. 1986. Biogenic silica and phosphorus accumulation in sediments as indices of eutrophication in the Laurentian Great Lakes. Hydrobiologia 143: 79-86.

Schelske C.L., Feldt L.E., Santiago M.A. and Stoermer E.F. 1972. Nutrient enrichment and its effect on phytoplankton production and species composition in Lake Superior. In: Proceedings 15th Conference of Great Lakes Research. Int. Assoc. Great Lakes Res., Ann Arbor, MI, pp. 149-163.

Schelske C.L., Rothman E.D., Stoermer E.F. and Santiago M.A. 1974. Responses of phosphorus limited Lake Michigan phytoplankton to factorial enrichments with nitrogen and phosphorus. Limnol. Oceanogr. 19: 409-419.

Schelske C.L., Simmons M.S. and Feldt L.E. 1975. Phytoplankton responses to phosphorus and silica enrichment in Lake Michigan. Verh. Int. Ver. Limnol. 19: 911-921.

Schelske C.L., Stoermer E.F., Conley D.J., Robbins J.A. and Glover R.M. 1983. Early eutrophication of the lower Great Lakes: new evidence from biogenic silica in sediments. Science 222: 320-322.

Siver P.A., Ricard R., Goodwin R. and Giblin A.E. 2003. Estimating historical in-lake alkalinity generation from sulfate reduction and its relationship to lake chemistry as inferred from algal microfossils. J. Paleolimnol. 29: 179-197.

Smol J.P. 1985. The ratio of diatom frustules to chrysophycean statospores: a useful paleolimnological index. Hydrobiologia 123: 199-208.
Smol J.P. 1995. Application of chrysophytes to problems in paleoecology. In: Sandgren C.D., Smol J.P. and Kristiansen J. (eds), Chrysophyte Algae: Ecology, Phylogeny and Development. Cambridge University Press, Cambridge, UK, pp. 303-329.

Stevens R.J. and Nielson M.A. 1987. Response of Lake Ontario to reduction in phosphorus load. Can. J. Fish. Aquat. Sci. 44: 2059-2068.

Stoermer E.F. 1993. Evaluating diatom succession: some peculiarities of the Great Lakes case. J. Paleolimnol. 8: 71-83.

Stoermer E.F. 1998. Thirty years of diatom studies on the Great Lakes at the University of Michigan. J. Great Lakes Res. 24: 518-530.

Stoermer E.F. and Kreis R.G.Jr. 1980. Phytoplankton composition and abundance in southern Lake Huron. USEPA, Office of Research and Development, Duluth, Minnesota, 396 pp.

Stoermer E.F. and Yang J.J. 1970. Distribution and relative abundance of dominant plankton diatoms in Lake Michigan. Great Lakes Res. Div., University of Michigan, Ann Arbor, Michigan, Spec. Rep 16, 64 pp.

Stoermer E.F., Emmert G. and Schelske C.L. 1989. Morphological variation of Stephanodiscus niagarae Ehrenb. (Bacillariophyta) in a Lake Ontario sediment core. J. Paleolimnol. 2: $227-236$

Stoermer E.F., Kociolek J.P., Schelske C.L. and Conley D.C. 1987. Quantitative analysis of siliceous microfossils in the sediments of Lake Erie's central basin. Diatom Res. 2: 113-134.

Stoermer E.F., Kociolek J.P., Schelske C.L. and Andresen N.A. 1991. Siliceous microfossil succession in the recent history of Green Bay, Lake Michigan. J. Paleolimnol. 6: 123-140.

Stoermer E.F., Kociolek J.P., Schelske C.L. and Conley D.C. 1985a. Siliceous microfossil succession in the recent history of Lake Superior. Proc. Acad. Natl. Sci., Philad. 137: 106-118.

Stoermer E.F., Ladewski B.G. and Schelske C.L. 1978. Population responses of Lake Michigan phytoplankton to nitrogen and phosphorus. Hydrobiologia 57: 249-265.

Stoermer E.F., Wolin J.A. and Schelske C.L. 1993. Paleolimnological comparison of the Laurentian Great Lakes based on diatoms. Limnol. Oceanogr. 38: 1131-1316.

Stoermer E.F., Wolin J.A., Schelske C.L. and Conley D.C. 1985b. An assessment of changes during the recent history of Lake Ontario based on siliceous microfossils preserved in the sediments. J. Phycol. 21: 257-256.

Stoermer E.F., Wolin J.A., Schelske C.L. and Conley D.C. 1985c. Variations in Melosira islandica valve morphology related to eutrophication and silica depletion. Limnol. Oceanogr. 30: 414 418.

Stoermer E.F., Wolin J.A., Schelske C.L. and Conley D.C. 1990. Siliceous microfossil succession in Lake Michigan. Limnol. Oceanogr. 35: 959-967.

ter Braak C.J.F. 1995. Ordination. In: Jongman R.H., ter Braak C.J.F.and van Tongeren O.F.T. (eds), Data Analysis in Community Ecology. Pudoc, Wageningen, pp. 91-173.

Tilman D., Kilham S.S. and Kilham P. 1982. Phytoplankton community ecology: the role of limiting nutrients. Annu. Rev. Ecol. Syst. 13: 349-372.

Theriot E.C. 1987. Principal component analysis and taxonomic interpretation of environmentally related variation in silicification in Stephanodiscus (Bacillariophyceae). Br. phycol. J. 22: 359-373 
Theriot E.C., Håkansson H. and Stoermer E.F. 1988. Morphometric analysis of Stephanodiscus alpinus (Bacillariophyceae) and its morphology as an indicator of lake trophic status. Phycologia 27: 485-493.

van der Werff A. 1955. A new method for concentrating and cleaning diatoms and other organisms. Verh. Int. Ver. Limnol. 12: 276-277.

Warwick W.F. 1980. Palaeolimnology of the Bay of Quinte, Lake Ontario: 2800 years of cultural influence. Can. Bull. Fish. Aquat. Sci. 206: 117.

Wolfe B.B., Edwards T.W.D. and Duthie H.C. 2000. A 6000 year record of interaction between Hamilton Harbour and Lake Ontario: quantitative assessment of recent hydrologic disturbance using ${ }^{13} \mathrm{C}$ in lake sediment cellulose. Aquat. Eco. Health Manage. 3: 47-54.

Wolin J.A. 1992. Paleoclimatic implications of late Holocene lake-level fluctuations in Lower Herring Lake, Michigan.
PhD thesis, University of Michigan, University Microfilms, Ann Arbor, Michigan, $155 \mathrm{pp}$.

Wolin J.A. 1996. Late Holocene lake-level and lake-development signals in Lower Herring Lake, Michigan. J. Paleolimnol. 15: 19-45.

Wolin J.A., Stoermer E.F. and Schelske C.L. 1991. Recent changes in Lake Ontario: 1981-1987: Microfossil evidence of phosphorus reduction. J. Great Lakes Res. 17: 229-240.

Wolin J.A., Stoermer E.F., Schelske C.L. and Conley D.C. 1988. Siliceous microfossil succession in recent Lake Huron sediments. Arch. Hydrobiol. 114: 175-198.

Wright H.E.Jr. 1991. Coring tips. J. Paleolimnol. 6: 37-49.

Yang J.R., Duthie H.C. and Delorme L.D. 1993. Reconstruction of the recent environmental history of Hamilton Harbor from quantitative analysis of siliceous microfossils. J. Great Lakes Res. 19: 55-71. 